\title{
MORPHO-ANATOMICAL FEATURES OF THE LEAVES AND STEMS OF BACCHARIS NOTOSERGILA (ASTERACEAE) AND THEIR RELATIONSHIP WITH THE ENVIRONMENT AND CHEMICAL CONTROL
}

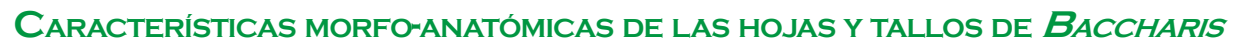 \\ NOTOSERGILA (ASTERACEAE) Y SU RELACIÓN CON EL AMBIENTE Y CONTROL \\ QUÍMICO
}

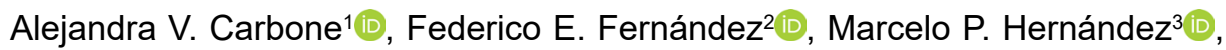 \\ Santiago M. Martínez Alonso ${ }^{4}$ and Ana M. Arambarri ${ }^{5}$
}

\begin{abstract}
1. Prof. Adjunta de Morfología Vegetal, Facultad de Ciencias Agrarias y Forestales (FCAyF), Universidad Nacional de La Plata (UNLP), La Plata, Argentina. Instituto de Fisiología Vegetal, (INFIVE-CONICET-UNLP)

2. Forrajicultura y Praticultura, FCAYF, UNLP

3. Laboratorio de Morfología Comparada de Espermatófitas (LAMCE). Sistemática Vegetal, FCAyF, UNLP. Botánica Sistemática II, División Plantas Vasculares, Facultad de Ciencias Naturales y Museo (FCNyM), UNLP

4. Técnico (INFIVE-CONICET-UNLP)

5. Prof. jubilada de Morfología Vegetal, Investigadora FCAyF, UNLP 1-5. FCAyF, UNLP, 60 y 119, C. C. 31 (1900) La Plata, Buenos Aires, Argentina.
\end{abstract}

*anaramba@gmail.com

Citar este artículo CARBONE, A. V., F. E. FERNÁNDEZ, M. P. HERNÁNDEZ, S. M. MARTÍNEZ ALONSO \&A. M. ARAMBARRI. 2021. Morpho-anatomical features of the leaves and stems of Baccharis notosergila (Asteraceae) and their relationship with the environment and chemical control. Bol. Soc. Argent. Bot. 56: 423-444.

DOI: https://doi. org/10.31055/1851.2372.v56. n4.33519

Recibido: 20 Jun 2021

Aceptado: 3 Set 2021

Publicado en línea: 4 Nov 2021

Publicado impreso: 20 Dic 2021

Editora: Ana María Gonzalez iD

ISSN versión impresa 0373-580X

ISSN versión on-line 1851-2372

\section{SUMMARY}

Background and aims: Baccharis notosergila is an aggressive weed inhabiting the Salado river basin, Buenos Aires province, Argentina. The aims were: to analyze the morpho-anatomy and histochemistry of aerial vegetative organs in order to understand the adaptation strategies that ensure its survival, as well as to expand knowledge on traits determining resistance to the control methods applied.

M\&M: The material collected was prepared and examined with conventional techniques of microscopy. Histochemical tests were performed.

Results: The major features found were small and deciduous leaves; uniseriate epidermis with massive and striate cuticle; stomata at level or slightly above the other epidermal cells and glandular trichomes secreting oily substances; stomata on both surfaces and isobilateral mesophyll. Starch, phenolic and lipophilic substances, and resins were identified in leaves and stems, and calcium oxalate crystals in leaves, stems and capitate trichomes.

Conclusions: The aerial vegetative organs features of $B$. notosergila explain its tolerance to the unfavorable conditions of the Salado river basin area, as well as its competitive ability over others species of the natural prairie. The reduced and deciduous leaves, the epidermal traits, and chemical substances found constitute a physical and chemical barrier reducing dehydration as well as the penetration of the herbicides applied for its control. Botanical knowledge of $B$. notosergila is the basis to develop new and appropiate management methods for this species.

\section{KEY WORDS}

Aboveground system, environmental adaptation, stress tolerance.

\section{RESUMEN}

Introducción y objetivos: Baccharis notosergila es una maleza agresiva que habita la Depresión del Salado, provincia Buenos Aires, Argentina. Los objetivos fueron: analizar la morfo-anatomía e histoquímica de los órganos vegetativos aéreos para entender las estrategias de adaptación que aseguran su sobrevivencia, así como profundizar el conocimiento sobre los caracteres que determinan la resistencia a los métodos de control.

M\&M: El material recolectado fue preparado y analizado con técnicas convencionales para microscopía. Se realizaron pruebas histoquímicas.

Resultados: Los principales caracteres encontrados fueron hojas pequeñas y caedizas, anfistomáticas con mesofilo isobilateral; epidermis uniseriada, cutícula masiva y estriada, estomas a nivel o ligeramente elevados y tricomas glandulares que secretan sustancias oleosas. Se identificaron sustancias lipofílicas y fenólicas, almidón y resinas en hojas y tallos y se hallaron cristales de oxalato de calcio en hojas, tallos y tricomas capitados.

Conclusiones: Las características de los órganos vegetativos aéreos de $B$. notosergila explican su tolerancia a las condiciones desfavorables del área de la Depresión del Salado, así como su habilidad competitiva y predominancia sobre otras especies de la pradera natural. Las hojas pequeñas y deciduas, sus características epidérmicas y sustancias químicas encontradas constituyen una barrera física y química para la deshidratación y penetración de los herbicidas aplicados para su control. El conocimiento botánico de $B$. notosergila es la base para el desarrollo de nuevos y apropiados métodos para el manejo de esta especie.

\section{Palabras ClaVe}

Adaptación ambiental, sistema vegetativo aéreo, tolerancia al estrés. 


\section{INTRODUCTION}

The genus Baccharis L. is the richest in species within the Astereae tribe, comprises from 354 species (Müller, 2013) to 440 (Heiden et al., 2019) of exclusively American distribution. Zuloaga et al. (2019) reported 210 species for southern cone of South America (Argentina, southern Brazil, Chile, Paraguay, and Uruguay). In Argentina inhabit 99 species (Giuliano \& Plos, 2014). The present contribution is about Baccharis notosergila Griseb., which is a woody shrub that inhabit in the Salado river basin situated in Buenos Aires province (Argentina). This region alternate cyclically periods of drought and floods, the land surface is nearly horizontal with predominance of saline-alkaline soils and a deficient drainage. This area is occupied by natural pastures and principally dedicated to livestock farming (Rodriguez \& Jacobo, 2012). Baccharis notosergila not only reduce with its cover the area accessible to grazing, but produce strong competition for water, nutrients and light with the species of value of the natural grassland, generating a process of degradation that normally result in low productivity (Sione et al., 2006). Baccharis notosergila in the Salado river basin has shown to be resistant to mechanical and chemical control (Urdampilleta, 2019; Carbone et al., 2019). For the reasons mentioned above, this species is included in the project on problematic weeds, developed in the Facultad de Ciencias Agrarias y Forestales, Universidad Nacional de La Plata (Argentina). In a previous paper, Carbone et al. (2019) analyzed the underground system in which was found a xylopodium with buds constituting a bud bank, either was detected in the radical system the accumulation of inulin as the principal reserve. According to Hayashi \& Appezzato-daGlória (2007) and Appezzatto-da-Glória \& Cury (2011), the presence of these two traits allow for regeneration and survival through unfavourable environmental conditions. Carbone et al. (2019), attributed to subterranean system's traits the capacity to sprout and develop new organs in the spring after mechanical and chemical control, and the accumulation of inulin reinforces the resprout and persistence of this shrub. Now, two questions arise: what is the role of aerial vegetative organs in the survival of this species?, and what is its reaction to the chemical control treatment?. Despite what has just been said, there is not a comprehensive study of aboveground system of $B$. notosergila. Therefore, the aims of this study were to investigate leaves and stems morphology, structure and histochemical features to ascertain whether a correlation exists between the leaves and stems traits and survival strategies, and to obtain some insight into the biological problems concerning the resistance to current control methods.

\section{Materials and Methods}

\section{Plant materials}

Plants of B. notosergila having fully developed leaves were collected during the spring of 20182020 in the "El Amanecer" establishmentfarm situated at $57^{\circ} 37^{\prime} \mathrm{W}, 35^{\circ} 15^{\prime} \mathrm{S}$ in Vieytes, Magdalena party (Pdo.), Buenos Aires province (Prov.), Argentina. The botanical material was identified and the vouchers were deposited in the herbarium of Facultad de Agronomía, Universidad Nacional de La Plata, and registered as: 17XII-2018, F. Fernández \& A. Carbone 1, 2, 3, 4 (LPAG); F. Fernández \& A. Carbone 5, 15-X-2019, (LPAG); F. Fernández \& A. Carbone 6 (specimen from half hill), 7 (specimen from alkaline-saline lowland), 8 (specimen from sweet lowland), 11XI-2020 (LPAG). In addition, specimens having leaves from Instituto de Botánica Darwinion were consulted. ARGENTINA. Prov. Buenos Aires: Pdo. Berazategui, Hudson, 16-IV-1927, Burkart 1302 (SI) (image 15). Prov. Entre Ríos: Dpto. Concordia, 31-I-1927, Burkart 1122 (SI), Det. Cabrera (image 14). Dpto. Gualeguaychú, 10-IV-1960, Burkart 21988 \& Gamerro (SI).

\section{Optical microscopy}

For anatomy study, mature leaves and stem fragments of different specimens were fixed in FAA (a solution of formaldehyde, glacial acetic acid, and $70 \%$ ethyl alcohol, Johansen, 1940), then stored in $70 \%$ ethanol. To analyze epidermis in surface view, the leaves were diaphanized using the method of Franklin (1945) modified, for that, the leaves were boiled in ethyl alcohol $96^{\circ}$ for $20 \mathrm{~min}$, allowed to cool were washed and bleached in $50 \%$ sodium hypochlorite $(\mathrm{NaClO})$ for $2 \mathrm{~h}$, washed twice and submerged in a solution of hydrogen peroxide + glacial acetic acid $(1: 1 \mathrm{v} / \mathrm{v})$ for $48 \mathrm{~h}$, washed twice 


\section{A. V. Carbone et al. - Baccharis notosergila: aerial vegetative organs and environment}

in distilled water, bleached again in $50 \% \mathrm{NaClO}$. At the completion of the bleaching process, five washes in distilled water were carried out to remove the $\mathrm{NaClO}$, and samples were then transferred into a solution of chloral hydrate $(5 \%)$ for $24-48 \mathrm{~h}$. To complete the process, some leaves were washed and stained with safranin or Oil red "O", on others was applied the peeling method to obtain the epidermis which were also stained. To analyze the structures, freehand cross-sections of stems, petiole and at leaf blade middle part of leaves were cut; the selected sections were bleached in $50 \%$ $\mathrm{NaClO}$, washed thrice with distilled water, then a successive double staining was performed with Alcian blue and safranin (Luque et al., 1996), on others a metachromatic staining was performed using Toluidine blue "O" $(0.05 \%)(\mathrm{O}$ 'Brien et al., $1964)$ or Cresyl brilliant blue (0.05\%) (Pérez \& Tomasi, 2002), and also a monochromatic staining was made using alcoholic solution of safranin (80\%) (D'Ambrogio, 1986). The sections, clarified leaves, and epidermis were mounted in gelatinglycerin on glass slides and sealed with nail polish.

The histochemical analysis was performed on freehand sections of leaf and stem samples. To test lipophilic substances an alcoholic solution of Oil red "O" was used (Gurr, 1971), the red color indicated positive test. Detection of phenolic compounds (tannins) was performed using ferric chloride $(10 \%)$ and sodium carbonate $(2 \%)$ (Zarlavsky, 2014), a green-blue color was a positive test. Starch was identified with IodinePotassium-Iodide (IKI) (Ruzin, 1999) a black-blue color indicate positive test. Resins were detected using a saturated solution of copper sulphate (Cosa et al., 2014) a color emerald green indicate positive test. Additionally, toluidine blue "O" was used to contrast polyphenols (Tapia-Torres et al., 2014), a color turquoise green was a positive test.

The leaf morphology and phyllotaxy type were evaluated through a visual inspection. To see details a Bausch \& Lomb stereomicroscope was used. Photographs were taken with a digital camera, resolution 12 MP. Slides were analyzed with a Nikon E200 LED optical microscope and using micrometrics SE Premium software. The measurements of outer periclinal epidermal cell walls and cuticle thickness in micrometers $(\mu \mathrm{m})$ were obtained by using ImageJ software (González, 2018). Terminology used by Metcalfe
\& Chalk (1988) was followed in this work. The stomata types were recognized using the manual of Ash et al. (1999). Trichomes were described considering the literary works (Ramayya, 1962; Freire et al., 2007; Tosoratto et al., 2016, and Budel et al., 2018).

\section{Scanning electron microscopy (SEM)}

It was performed using portions of stem and leaf blade. They were taken from fixed material, dehydrated in ethyl alcohol $\left(100^{\circ}\right)$ for $24 \mathrm{~h}$. Then the samples were affixed on stubs by double-sided adhesive tape and were submitted to metallization with a fine and thin gold layer. Afterwards they were examined with a Philips 505 SEM, and micrographs were prepared. Center for Research and Development in Applied Sciences "Dr. Jorge J. Ronco" (CINDECA), National Council for Scientific and Technical Research (CONICET), National University of La Plata (UNLP).

\section{Results}

\section{Leaf morphology}

Leaves are deciduous and have an alternate arrangement. They are variable in shape and size. They are elliptic or elliptic-obovate, linear-elliptic and linear. The largest elliptic or elliptic-obovate frequently are situated in the basal part of the plant or stems, the linear-elliptic towards the middle part, and the linear leaves at the top of the stem or the upper branches of the plant. All leaves have acutemucronate apex, decurrent base with petiole, and reticulate vascularization. The largest leaves have the serrate margins with $1-4(-10)$ teeth on each margin; $3.7-7 \mathrm{~cm}$ long and $0.5-1 \mathrm{~cm}$ wide. The median leaves have a few teeth or entire margins, $2.3-4.2 \mathrm{~cm}$ in length and $0.3-0.5 \mathrm{~cm}$ in width, and the smallest linear leaves have entire margins, measuring 1-2.5 cm long x 0.1-0.3 cm wide (Fig. 1).

\section{Epidermal tissue in surface view by SEM}

The leaves epidermis exhibit striate and massive cuticle and frequently waxes overlap the guard cells, partly obscuring them (Fig. 2A). Stem topography view by SEM reveals longitudinal ribs alternating with grooves, all covered by striate cuticle, and the stomata located in the depth of the grooves (Figs. 2 B; 8B). 


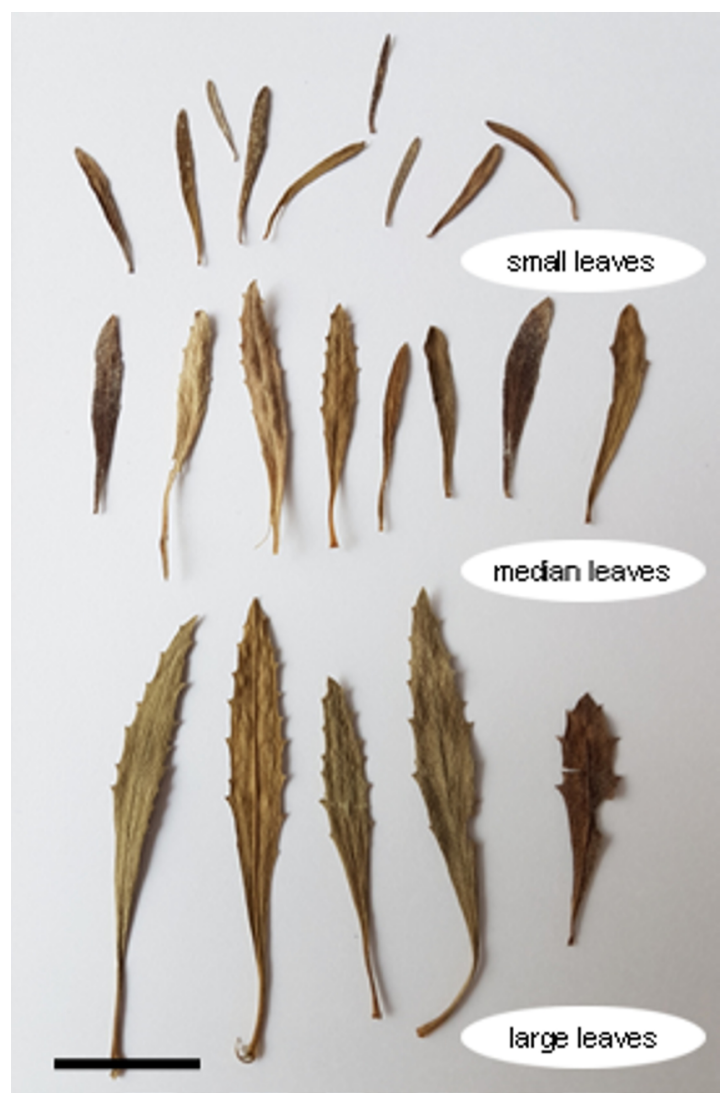

Fig. 1. Leaf morphology. It shows the variability of $B$. notosergila leaf size and shapes. The large elliptic and elliptic-obovate leaves (3.7-7 cm length); with toothed margins, and it may be seen the reticulate venation. The median elliptic and linear-elliptic leaves (2.3-4.2 cm length), with toothed or entire margins. The small linear leaves $(1-2.5 \mathrm{~cm}$ length), with entire margins. Scale: $2 \mathrm{~cm}$.

\section{Epidermal tissue in surface view by light microscope}

The epidermal cells on both leaf blade faces are polygonal with anticlinal cell walls straight to slightly wavy, and the cuticle is striated especially around the trichomes and stomata. Generally, the anticlinal cell walls are thin. Stomata are uniformly distributed over whole petiole and leaf blade surfaces and on the margins. They are randomly distributed, however, the stomata longitudinal axis is oriented following the longitudinal axis of the organ (Fig. 2A). Stomata are predominantly actinocytic, anomocytic, anomotetracytic, cyclocytic types and less frequently anisocytic. Each stoma shows in surface view the outer stomatal ledge, a polar thickening, and ellipsoidal stomatal aperture (pore) (Fig. 3A-E). The trichomes are found on both leaf blade surfaces, margins, and the petiole. The trichomes types are: (i) Biseriate capitate glandular with 2 basal cells and 6-8 cells which contains druses (Fig. 4A); (ii) Bulbiferous flagelliform glandular (bfg) type II, uniseriate and curved body with 3-7 (frequently 4) rounded cells, the terminal swollen spherical, and a translucent flagellum-like apical cell (Fig. 4B), less frequently are found bfg type I with straight body of 5-7(-8) cells and flagellum cell (Fig. 4D); (iii) Uniseriate capitate glandular trichome composed by one basal cell, 2-6(-8) stalk cells and a multicellular head (Fig. 4C). All the trichomes have basal cells cutinized, given positive reaction for lipophilic compounds, and are responsible for the secretion of oil droplets deposited over the leaf blade surface (Fig. 4D-F). The biseriate glandular trichomes can be seen forming a tuft themselves (Fig. 4A), but frequently appear clustered with bfg trichomes (Fig. 4B, D-G) in tufts and localized in a small epidermal depression. Either of the bfg trichomes can occur singly. It was observed that frequently two or three tufts appear connected by more elongated epidermal cells with cuticular thickened over the anticlinal cell walls (Fig. 4G). The uniseriate capitate trichomes are found in lower frequency and solitaries (Fig. 4C).

The caulinar axis exhibits epidermal cells tangentially elongated on the ribs with slightly thick anticlinal cell walls, and the surface covered by waxes; in the grooves there are numerous actinocytic stomata and trichome tufts (Figs. 3F; 4B).

\section{Leaf structure}

The petiole cross section next to attach the stem (basal part) shows a concave adaxial side forming two lobes (Fig. 5A). This cross-section exhibits quadrangular or rectangular epidermal cells, covered by cuticle. The angular collenchyma occurs in each lobe and some layers are found at middle vein level. The parenchyma is composed by rounded cells except the chlorenchyma which is formed by palisade parenchyma on the abaxial side, except at middle vein level. There are three main vascular bundles and some traces. The cross section in the middle part of the petiole length (Fig. 5B), exhibits a reduction of adaxial concavity; the collenchyma 


\section{A. V. Carbone et al. - Baccharis notosergila: aerial vegetative organs and environment}
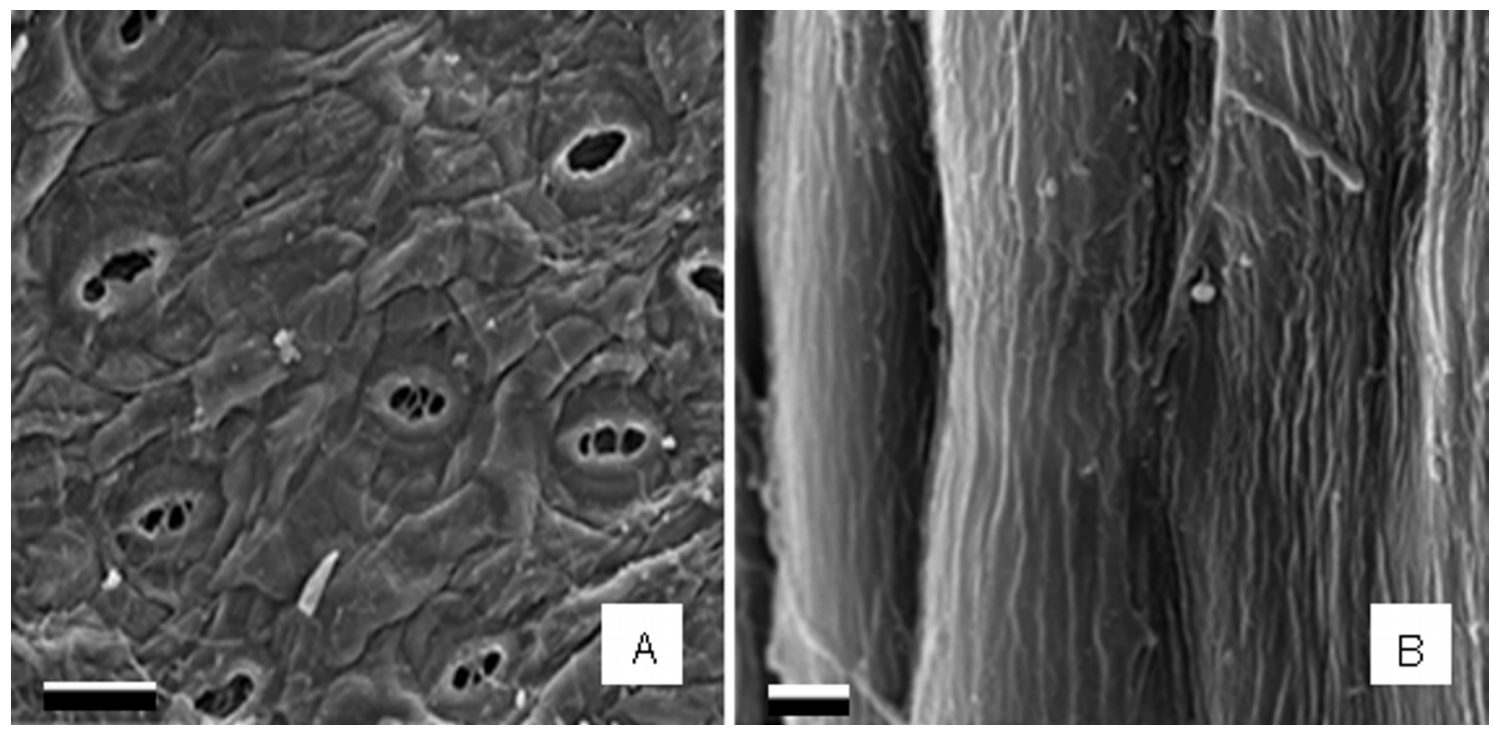

Fig. 2. Leaf and stem surface view by SEM. A: Leaf epidermis with massive cuticle and waxes over the stomata. B: Stem showing ribs and grooves covered by striate cuticle. Scales=A: $50 \mu \mathrm{m} ; \mathrm{B}: 5 \mu \mathrm{m}$.

appears as one continuous subepidermal layer, increasing the layers at midvein level, and the chlorenchyma begin to extend to adaxial side. The petiole cross section at the base of leaf blade (distal part, Fig. 5C), shows deltoid outline, however at midvein level there are adaxial and abaxial prominences, and the palisade chlorenchyma is present on both sides except at middle vein level; the wings of the leaf blade begin to appear. Along the entire length of the petiole there are three main vascular bundles. Each vascular bundle has fiber caps on the xylem and phloem sides, and one to three secretory ducts next to phloem fiber cap, all surrounded by a parenchyma sheath (Fig. 5D).

The leaf blade cross section exhibits the uniseriate epidermis formed by quadrangular or rectangular epidermal cells with periclinal cell walls thin or conspicuously thicker, always covered by a thin and striate cuticle (Fig. 6A, B). The stomata are localized above or at level with the surrounding epidermal cells, and the guard cells show conspicuous outer and inner stomatal ledges (Fig 6A, B). Internally the isobilateral mesophyll shows 2-3 layers of palisade parenchyma on both faces interrupted at middle vein level, but continuous in the margins (Fig. 6C), sometimes separated from the epidermis by collenchyma
(Fig. 6D). In the center, there are 3-4 layers of colorless dense spongy parenchyma (Fig. 6C). The vascular system is composed by collateral vascular bundles each surrounded by a parenchyma sheath, and cross the spongy parenchyma (Fig. 6C). The xylem always is to the upper side. The middle vein exhibits in the center one collateral vascular bundle with fiber cap adjoining the xylem and one to three secretory ducts next to phloem, all surrounded by a parenchyma sheath adding several layers of thin-walled parenchyma cells that connect with two or three layers of angular collenchyma below the epidermis, on both sides (Fig. 6E). The schizogenous secretory ducts exhibits a single layered epithelium composed of 4-6 cells (Fig. 6DE). In all materials analyzed the linear-elliptic and linear leaves have fiber cap only on the xylem side, and they have ample ducts, while in the largest elliptic or elliptic-obovate leaves the vascular bundles have fiber caps on xylem and phloem sides (similar occurs in the petiole), and the duct exhibit a reduced size (Fig. 6F). The teeth found on apex and margins of the leaves present hydathode structure, each tooth shows three vascular bundles which converge approaching the tooth end, the epithema is poorly developed and there is an open stoma at the tooth apex. 
Bol. Soc. Argent. Bot. 56 (4) 2021
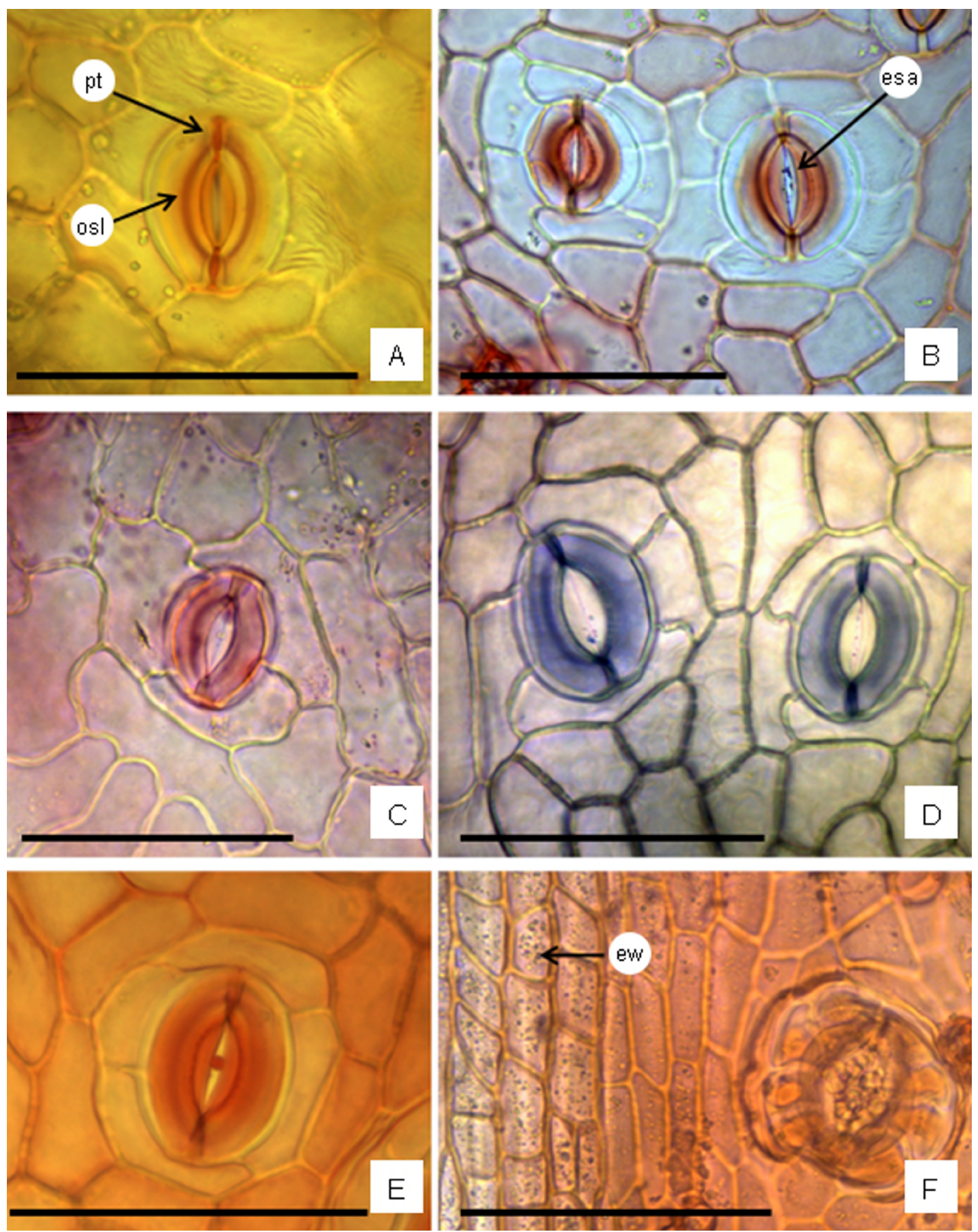

Fig. 3. Leaf and stem surface view by light microscope. A-E: Leaf. A: Anomocytic stoma, it exhibits the outer stomata ledge and polar thickening; cuticular striaes are notable on subsidiary cells. B: Two actinocytic stomata. C: Anisocytic. D: Anomocytic stoma on the left and anomotetracytic on the right. E: Ciclocytic. F: Epidermis of stem in surface view showing rectangular epidermal cells with anticlinal cell walls straight and thickened; epicuticular waxes visible as points on the surface, and an actinocytic stoma. Abbreviations= esa: ellipsoidal stomata aperture; ew: epicuticular waxes; pt: polar thickening; osl: outer stomata ledge. Staining= A, B, E, F: oil red "O"; C: safranin; D: toluidine blue "O". Scales= A-F: $100 \mu \mathrm{m}$. 

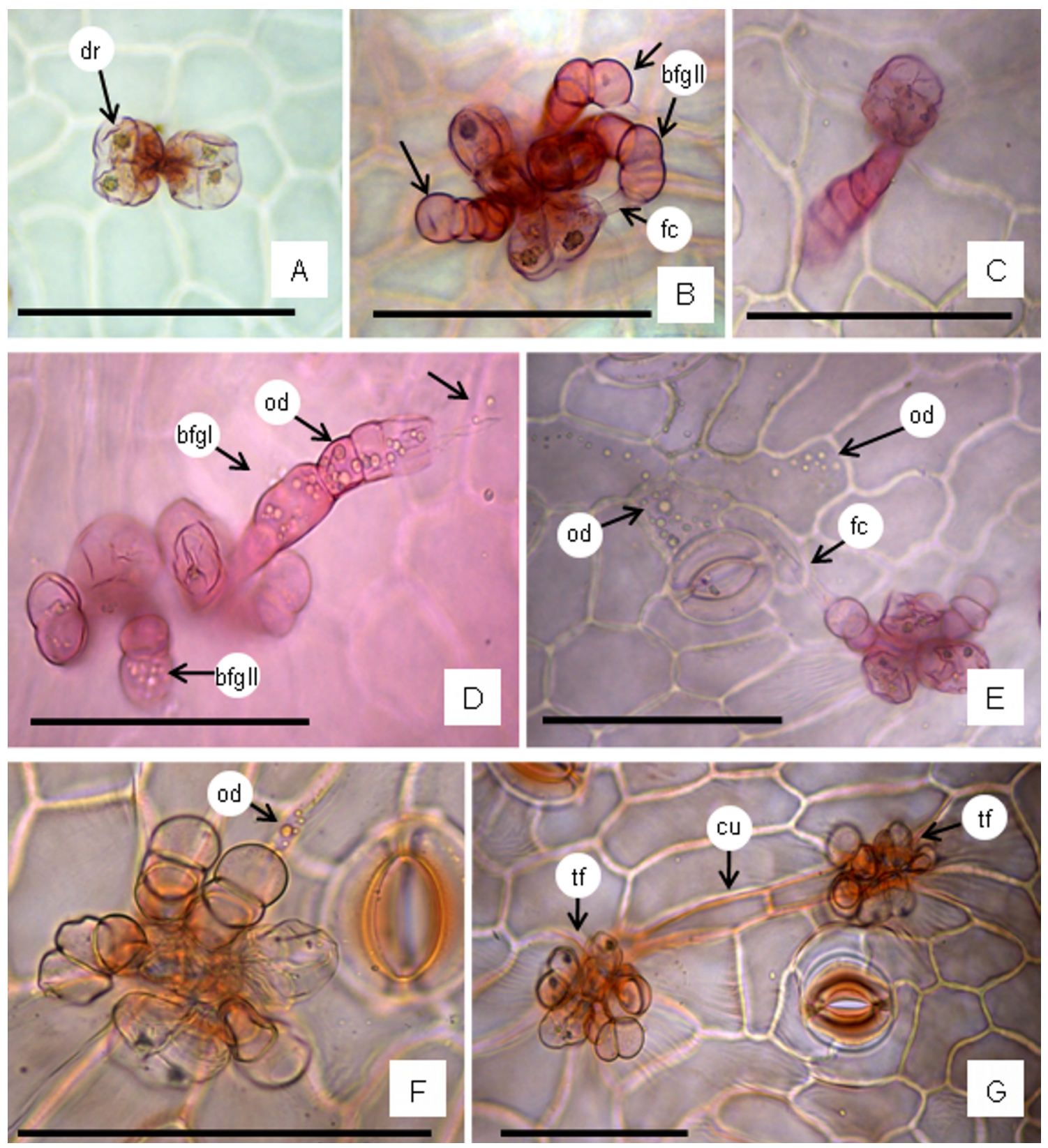

Fig. 4. Trichome features. A: A tuft with two biseriate capitates glandular trichomes showing druses in cells. B: A tuft showing three biseriate capitate trichomes clustered with three bulbiferous flagelliform glandular (bfg) type II (arrows). C: Uniseriate capitate trichome, solitary, rarely was seen in large leaves. D: A tuft showing biseriate capitate trichomes clustered with bfg type II, and one bfg type I (straight) with numerous oil droplets inner the trichome cells (arrows). E: A tuft showing the secretion of oil droplets and deposited on the epidermal cells surface. F: A tuft exhibiting oil droplets in the flagellum cell. G: Two tufts connected by elongated epidermal cells with cuticular thickened on the anticlinal epidermal cell walls. Abbreviations= bfgl: bulbiferous flagelliform glandular straight (type I); bfgll: bfg curved (type II); cu: cuticle; dr: druses; fc: flagellum cell; hd: head; od; oil droplets; st: stalk cells; tf: tuft. Staining= A-E: safranin; F, G: oil red "O". Scales: $A-G=100 \mu \mathrm{m}$. 

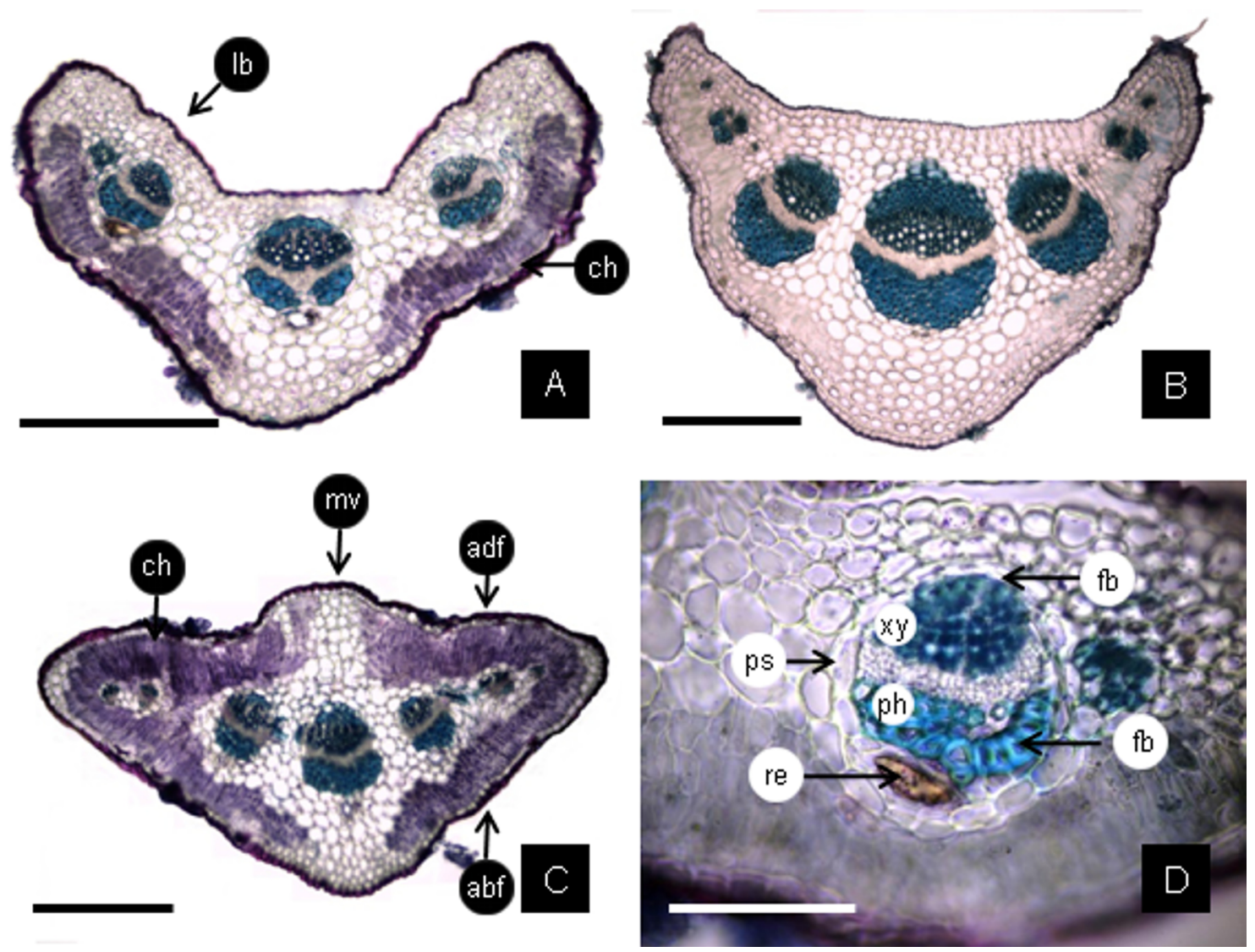

Fig. 5. Petiole cross section (CS). A: The CS near the insertion point on the stem is bilobed with chlorenchyma on abaxial side except at middle vein; there are three main vascular bundles. B: The CS in middle of the petiole length shows a reduction of lobes. C: The CS at base of the leaf-blade has a deltoid outline beginning to develop the wings of the leaf-blade with chlorenchyma on both faces, except at middle vein. D: detail of one vascular bundle showing caps of fibers on the xylem and phloem sides, and on the phloem side one duct; all surrounded by the parenchyma sheath. Abbreviations= abf: abaxial face; adf: adaxial face; ch: chlorenchyma; fb: fibers; lb: lobe; mv: middle vein; ph, phloem; ps: parenchyma sheath; re: resins; $x y$, xylem. Scales $=$ A-C: $300 \mu \mathrm{m}$; D: $100 \mu \mathrm{m}$.

The histochemical tests showed that some epidermal cells are filled with tanniniferous substances, the guard cells of stomata also contain tannins and starch, and these compounds are abundant in the mesophyll (Fig. 7A, B). In the mesophyll, especially in the palisade parenchyma cells there are many chloroplasts, oil bodies (Fig. 6B), and small prismatic crystals (Fig. 7C). In the epithelial cells of ducts were identified oil droplets of volatile oils (Fig. 6E) and in the cavity were obtained positive reactions for resins and polyphenols (Fig. 7D).
Comparing leaves structures collected from plants inhabiting on half hill, alkaline-saline lowland and sweet lowland in the studied area

The leaves from half hill exhibit in surface view, thickened anticlinal epidermal cell walls, and striated cuticle; on the teeth the epidermal cells shows thicker cell walls. In cross section both epidermis, adaxial and abaxial, show conspicuous cellulosic thicker on the cell walls; in the periclinal epidermal cell walls the thickness ranged between 5.6-20.6 $\mu \mathrm{m}$ with a mean value of $14.2 \mu \mathrm{m}$ (Fig. 6B). The leaves from alkaline-saline soils and from sweet lowland 


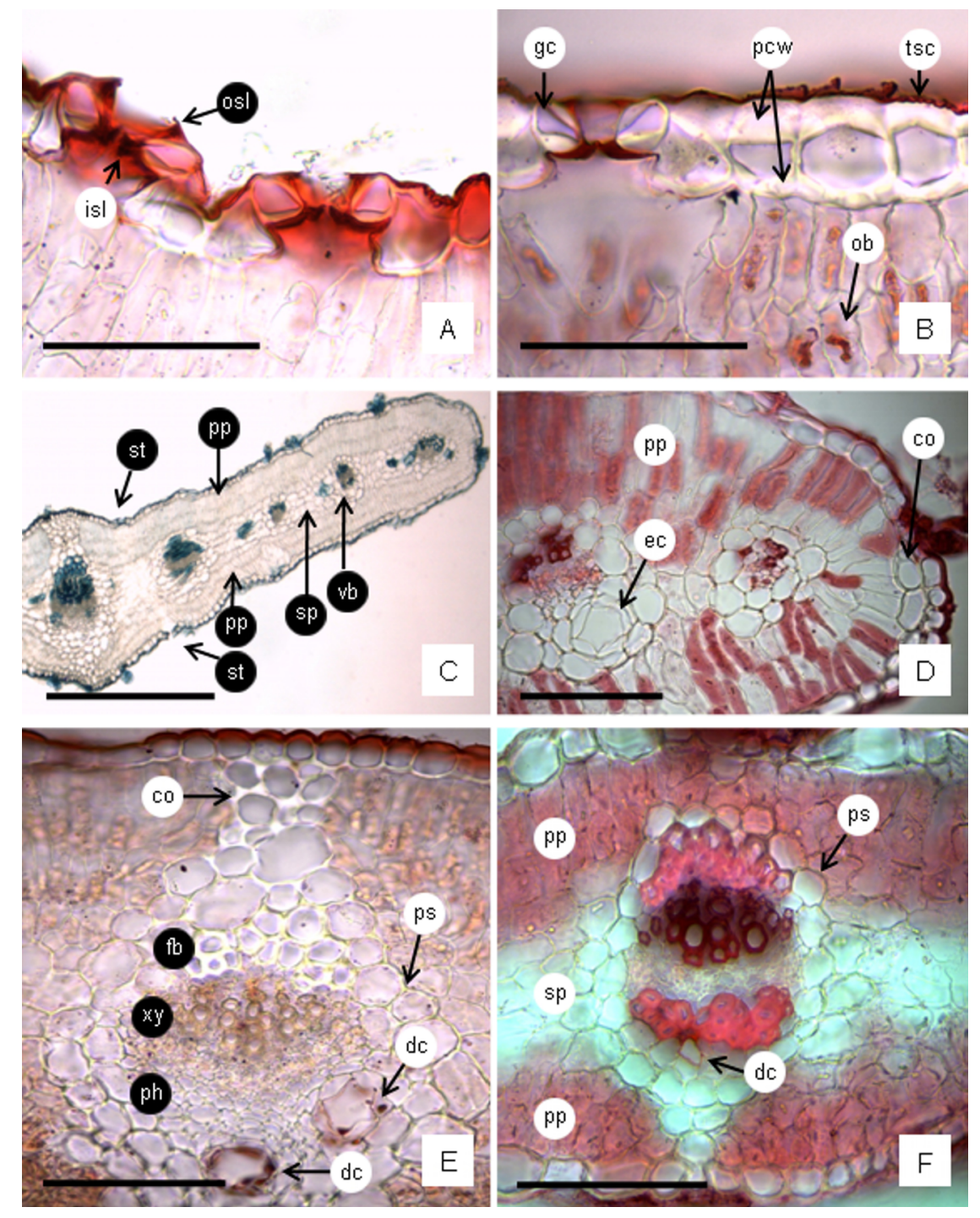

Fig. 6. Leaf blade cross section (CS). A: epidermal cells with thin cell walls and thin cuticle, the stomata slightly above the other epidermal cells, and the stoma guard cells with the cuticle forming conspicuous stomatal ledges. B: epidermal cells with thick periclinal cell walls, thin and striate cuticle, and stomata guard cells at level. Also may be seen the oil bodies in the mesophyll. C: Leaf-blade CS showing the prominences at middle vein level, the uniseriate epidermis, stomata and trichomes on sides, isobilateral mesophyll and vascular bundles $(\mathrm{vb})$ across the spongy parenchyma. $\mathbf{D}$ : a detail of the obtuse margins showing the palisade parenchyma continuous, separated from epidermis by some collenchyma cells; and marginal vascular bundles, one with an ample duct. E: middle vein CS of a linear-elliptic leaf showing the collateral vb with fibers on the xylem side and two ample ducts on the phloem side containing volatile oils in the epithelial cells, all surrounded by a parenchyma sheath and its extension towards the angular collenchyma cells. F: middle vein CS of an large elliptic-obovate leaf showing the collateral vb with fibers on both sides and one reduced duct on the phloem side, all surrounded by a parenchyma sheath and its extension to under epidermal collenchyma tissue. Abbreviations= co: collenchyma cells; dc: duct; ec: epithelial cells; fb: fibers; gc: guard cells; isl: inner stomatal ledge; ob: oil bodies; osl: outer stomatal ledge; pcw: periclinal cell walls; ph: phloem; pp: palisade parenchyma; ps: parenchyma sheath; sp: spongy parenchyma; st: stomata; tsc: thin and striate cuticle; vb: vascular bundle; xy: xylem. Scales: A, B, D-F: $100 \mu \mathrm{m}$; C: $500 \mu \mathrm{m}$. 

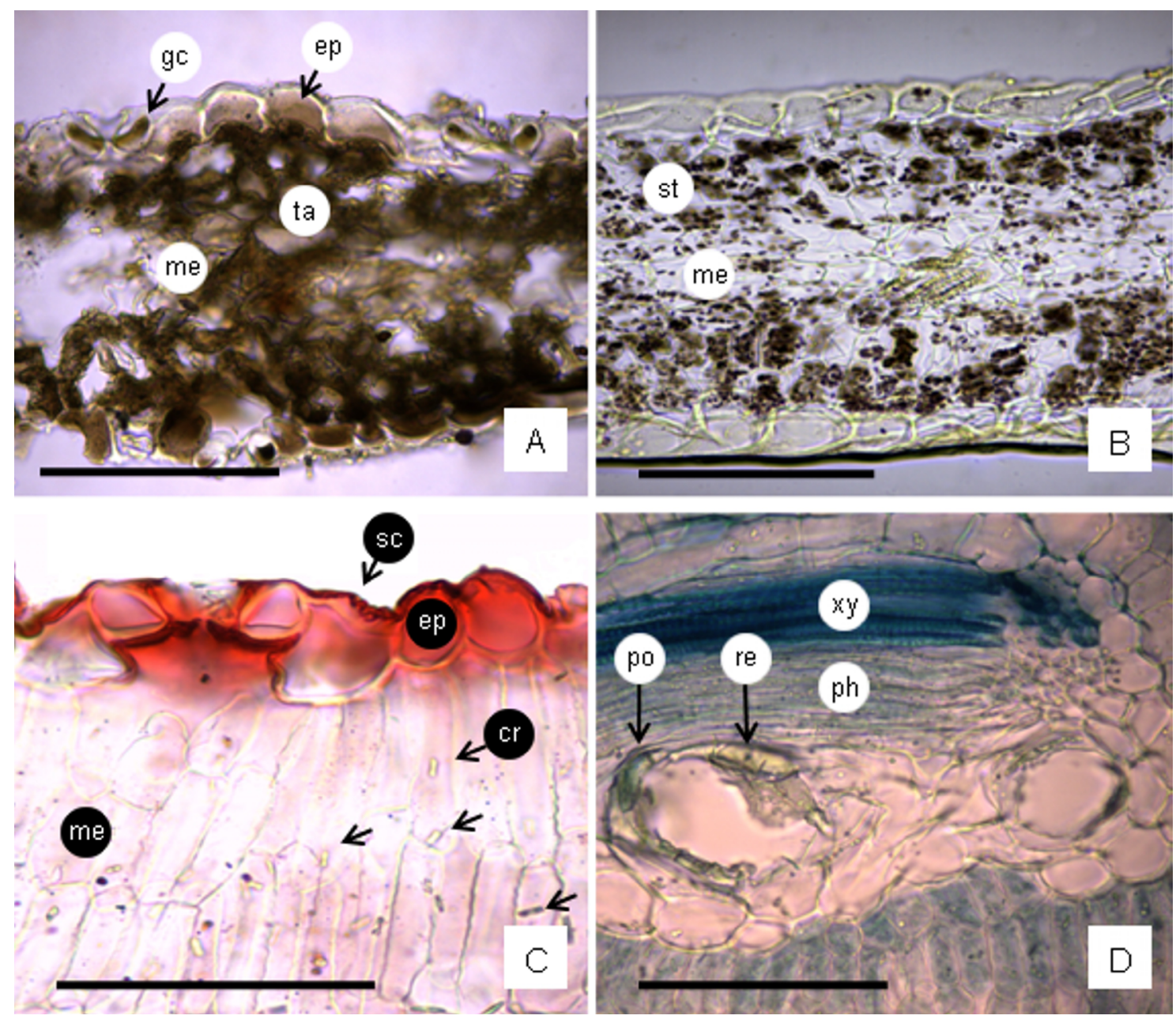

Fig. 7. Leaf histochemical tests and crystals. A: Leaf blade cross-section (CS) showing presence of tannins in epidermal cells, guard cells and mesophyll cells (test $\mathrm{FeCl} 3$ ). B: leaf blade CS showing starch grains in mesophyll cells (test IKI). C: Leaf blade CS showing thin and striate cuticle (test oil red "O"); small crystals in parenchyma cells (arrows). D: Vascular bundle showing two secretory ducts containing polyphenols and resins (tests toluidina blue "O" and copper sulphate have been made). Abbreviations= cr: crystals; ep: epidermis; gc: guard cells; me: mesophyll; ph: phloem; po: polyphenols; re: resins; sc: striate cuticle; st: starch grains; ta: tannins; xy: xylem. Scales= A-D: $100 \mu \mathrm{m}$.

show in surface view, thin anticlinal epidermal cell walls, and slightly striated cuticle. In cross section, the periclinal epidermal cell walls thickness ranged between 0.9-3.6 $\mu \mathrm{m}$ with a mean value of $2.3 \mu \mathrm{m}$ and $1.7 \mu \mathrm{m}$, respectively (Fig. 6A). The cuticle in all leaves is thin $(0.4-2.7 \mu \mathrm{m})$ with a mean value of 1.2-1.6 $\mu \mathrm{m}$ (Fig. 6A, B). The stomata in the leaves from alkaline-saline and sweet lowland are localized somewhat elevated above to the other epidermal cells (Fig. 6A) while in the leaves from half hill they appeared localized at level (Fig. 6B). The leaves from half hill shows the palisade parenchyma with abundant oil bodies (Fig. 6B), compared to leaves from alkaline-saline and sweet lowland.

\section{Stem structure}

A young stem of 1-2 mm diameter, in crosssection, reveals a wavy outline with eight ribs 


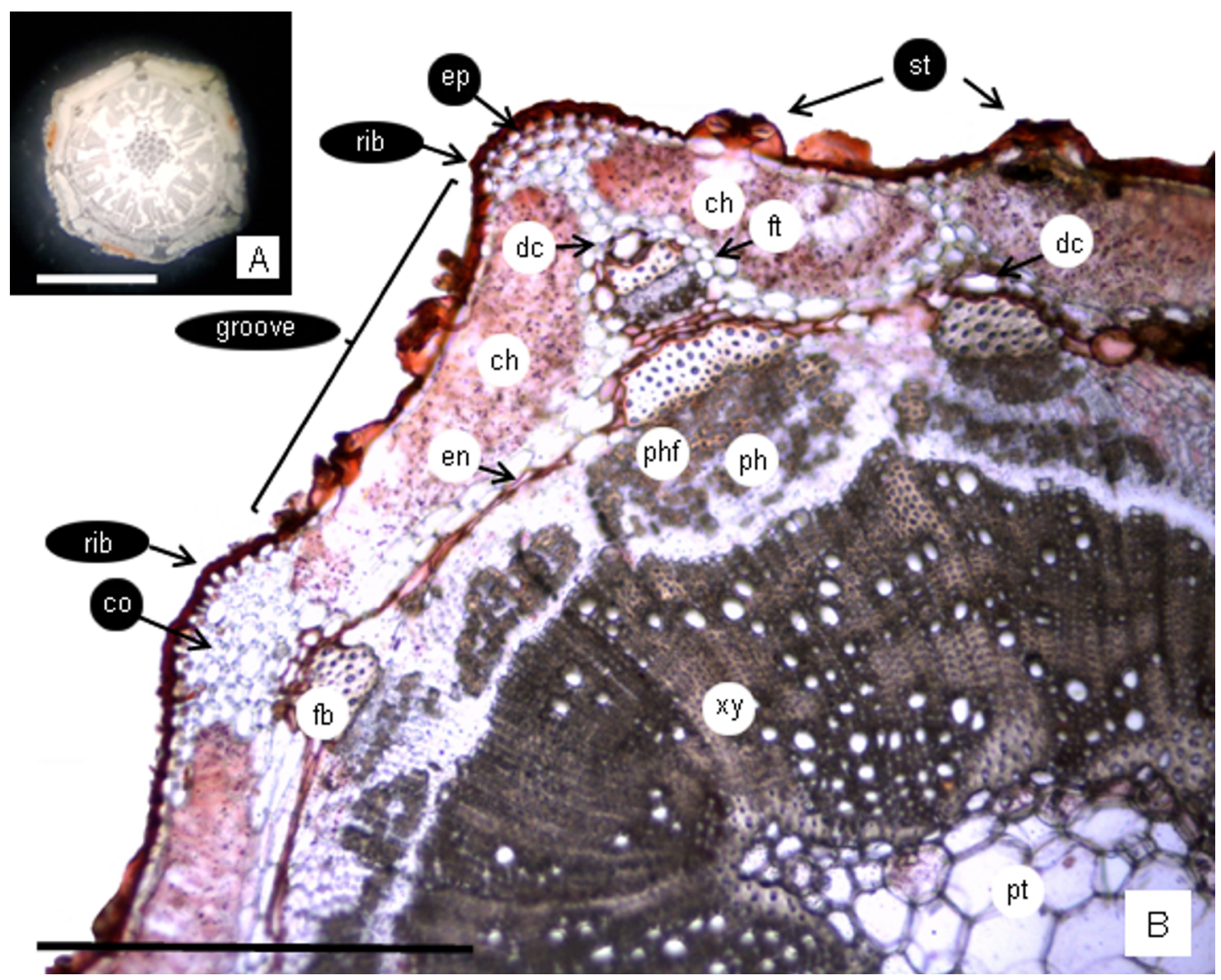

Fig. 8. Stem outline (1-2 mm diam.) and tissues in cross section. A: stem outline showing eight lobes or ribs. B: Stem tissues: ch, chlorenchyma; co, collenchyma; en, endodermis; ep, epidermis; fb, fiber clusters; $\mathrm{ft}$, foliar trace; ph, secondary phloem; phf, secondary phloem fibers; pt: pith; dc, duct; st, stomata; $x y$, secondary xylem. Scales $=A: 1 \mathrm{~mm} ; \mathrm{B}: 400 \mu \mathrm{m}$.

and alternating grooves (Fig. 8A). The epidermis is unilayered and consists of quadrangular or rectangular cells. The external periclinal walls of the cells are thick and impregnated with lipids and are covered by a cuticle of 1.2-3 $\mu \mathrm{m}$ thick. Stomata are localized in the grooves and are elevated above the adjacent epidermal cells (Fig. 8B). In the outer cortex, two to six layers of angular collenchyma are present beneath the ribs. Between the collenchyma, three to four layers of palisade chlorenchyma occur in the grooves. The inner cortex comprises two or three layers of polygonal parenchyma cells, and the innermost layer is the endodermis surrounding the vascular cylinder. In the cortex, a few vascular bundles corresponding to foliar traces are present. They each contain xylem internally and phloem externally with a cap of phloem fibers and a secretory duct adjacent to the fibers. The vascular bundle is surrounded by a parenchyma sheath with cell walls impregnated with lipophilic substances. The endodermis is formed by rectangular cells with thin cell walls impregnated with suberin, obscuring the Casparian strips. In the vascular cylinder, fiber clusters are found adjoining the phloem, and also fibers are in the secondary phloem. The secretory ducts with a uniseriate epithelium formed by $4-10$ cells occur in front of the phloem. The secondary xylem has 

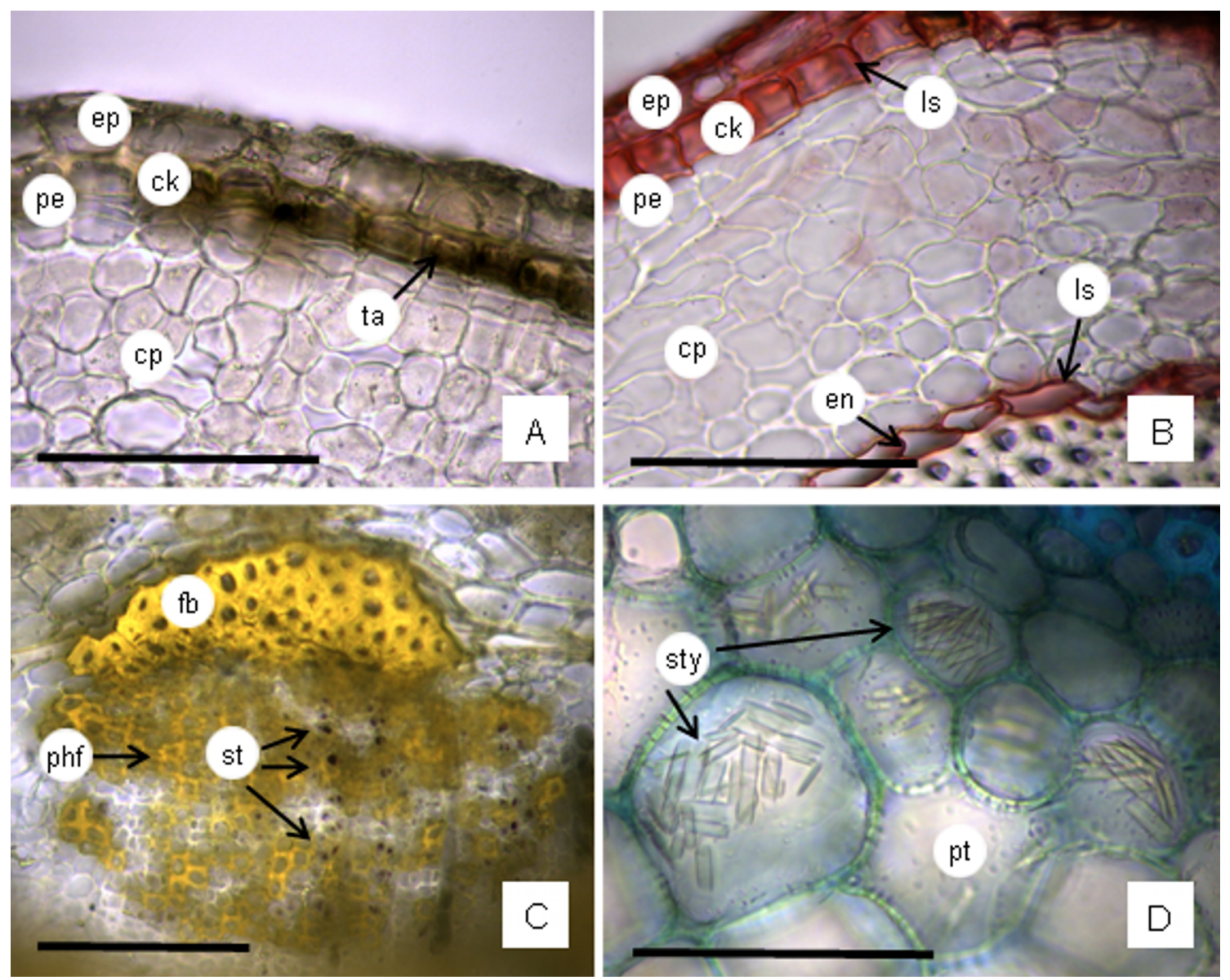

Fig. 9. Stem (3-4 mm diam.) in cross section. A: secondary bark (periderm) developed under the epidermis; cork cells contain tannins (test ClFe3). B: This photograph shows cutin in the epidermis; lipophilic substances in cork cell walls and in the endodermis cell walls (test oil red "O"); in the cortex may be seen isodiametric parenchyma cells. C: Secondary phloem with fibers and starch grains (test IKI). D: pith with crystals. Abbreviations= ck: cork; $c p$ : cortical parenchyma; en: endodermis; ep: epidermis; fb: fiber cluster; Is: lipophilic substances; pe: periderm; phf: fibers in the secondary phloem; pt: pith; st: starch grains; sty: styloids; ta: tannins. Scales= A-D: $100 \mu \mathrm{m}$.

fibers as the predominant component and tannins are occasionally found in the secondary xylem. The center of the stem is filled with the pith formed by thin-walled parenchyma cells. In the perimedullary cells, calcium oxalate crystals are observed (Fig. 8B).

A caulinar axis of 3-4 mm diameter exhibits rounded outline and similar structure as was described above, however the periderm (cork + cork cambium + phelloderm) is developed below the epidermis (Fig. 9A, B). The cork cells contain tannins (Fig. 9A). The cork cell walls are impregnated by suberin (Fig. 9B). In the cortex, the cortical parenchyma exhibits rounded cells, and the most inner cell layer, the endodermis, also shows cell walls impregnated with lipophilic substances (Fig. 9B). Internally, the parenchyma of the secondary phloem contains starch grains (Fig. 9C). In the medullary rays and pith there are abundant crystals which have very thin tabular shape that according to the focal distance may be confused with raphides (Fig. 9D). 


\section{A. V. Carbone et al. - Baccharis notosergila: aerial vegetative organs and environment}

\section{Discussion}

Leaf morphology. The leaves arrangement and features found in B. notosergila accord well with description of Baccharis leaves reported by Heiden et al. (2009). The petiole is not common in Baccharis leaves, however it has been found in several species (e. g., Souza et al., 2011; Jasinski et al., 2014; Bobek et al., 2016; Tosoratto et al., 2016). Respect to the variability of leaf margins dentate or entire, is common trait for the genus (Budel \& Duarte, 2008; Oliveira et al., 2011; Souza et al., 2011). Baccharis notosergila has leaves generally with reduced foliar expansion and stay on the plant about five months in spring and beginning summer. This is the best period to do photosynthesis. The character deciduous of the leaves is a favorable feature to the economy of water without affect its physiology, because it can continuous doing photosynthesis with its numerous younger green stems which have active palisade chlorenchyma. It would be an adaptation to the environment (Roth, 1984). On the other hand, the deciduous, small and narrow leaves would be unfavorable to penetration of herbicide treatments.

Hydathodes. Teeth found in leaves are hydathodes. The structure has been found in Asteraceae and in some species of Baccharis (Smiljanic, 1969; Lersten \& Curtis, 1985). The function is to discharge water (guttation), however, it would be interesting to do a more comprehensive study about the structure and function in $B$. notosergila.

Epidermal cells and cuticle. The polygonal epidermal cell shapes in surface view found in Baccharis notosergila accords well with the genus pattern (Ariza Espinar, 1973), while the anticlinal cell walls straight to slightly wavy also have been reported for some species (Cortadi et al., 1999; Freire et al., 2007; Budel \& Duarte, 2008; Oliveira et al., 2011; Souza et al., 2011; Bobek et al., 2015). The cuticle of $B$. notosergila in surface view appears massive and striated in leaves and stems, but it is always thin. These cuticle traits coincide with the most cases reported in the literature (Ariza Espinar, 1973; Cortadi et al., 1999; Budel et al., 2003; Budel \& Duarte, 2007; Petenatti et al., 2007; Jasinski et al., 2014; Bobek et al., 2015, 2016; Budel et al., 2018).
The epidermal cells and cuticle features may be attributed to environmental factors. Roth (1984), reported that when the foliar epidermis is exposed greater luminosity and reduced humidity develop characters of the "sun leaves", such as the straight epidermal anticlinal cell walls. Nughes et al. (2013) found the principal factor producing the "sun leaves" is the high light intensity, whereas they suggested the humidity is related to the stomata number and size. In $B$. notosergila, the linear leaves predominantly found in the high part of the plants, show the most reduced size and present epidermal anticlinal cell walls slightly thickened, also the epidermal periclinal cell walls conspicuously thickened were found in elliptic-obovate leaves collected in half hill. These features may be adaptations to more exposed localization to weather factors such as wind, high light intensity, because straight and thick periclinal cell walls tend to decrease the excessive loss of water (Fahn \& Cutler, 1992), and prevent cell collapse due to dehydration (Cosa \& Dottori, 2010). The striated cuticle would be a response to the environment as prevent rapid dehydration (Fahn \& Cutler, 1992). The massive aspect found in the cuticle would be produce by waxes deposited over the cuticle (Barthlott et al., 1998). Cuticle and epicuticular waxes also constitute the outermost defensive barrier of plant leaves against pathogens because their repellents properties (Barthlott et al., 1998; Stenglein et al., 2005). In cross sections the cuticle was found thin, however the chemical composition of the cuticle is of a great importance limiting transpiration, and thin cuticles are often effective in preventing excessive cuticular transpiration (Merida et al., 1981). The chemical weed control is more difficult in those species which have less foliar area and thicker cuticle and epicuticular waxes (Westwood et al., 1997; Dall'Armellina \& Zimdahl, 1989; Carbone, 2015), whereas a thin cuticle could be an advantage for the penetration of the herbicide, and therefore, increase its absorption into the inner tissues (Santier \& Chamel, 1992), however in this case the epicuticular waxes and volatile oils over the leaves and stem surfaces could be a barrier to penetration the herbicides or phytosanitary treatments applied.

Stomata types. Actinocytic, anisocytic, anomocytic, anomo-tetracytic and cyclocytic types 
of stomata were found in B. notosergila. According to Metcalfe \& Chalk (1950), the Asteraceae family may present anomocytic and anisocytic stomata, being the former predominant. These two types have been also reported in the genus by Ariza Espinar (1973), and were described for most species of Baccharis (Cortadi et al., 1999; Budel et al., 2004; Budel \& Duarte 2007, 2008, 2010; Petenatti et al. 2007; Souza et al., 2011; Tosoratto et al., 2016). However, cyclocytic was previously referred for B. notosergila (Freire et al., 2005, 2007), and several authors mentioned tetracytic type (e. g., Freire et al. 2007; Bobek et al., 2015, 2016; Budel et al., 2018; Ornellas et al., 2019). The actinocytic stomata type was mentioned by Freire et al. (2007) for 11 species of Baccharis, and Pereira et al. (2014) for B. milleflora DC. On the other hand, different stomata types in the same epidermis of one species of Baccharis have been previously encountered (Pereira et al.; 2014; Budel et al., 2015; Bobek et al., 2015, 2016; Budel et al., 2018; Ornellas et al., 2019).

Stomata distribution. Baccharis notosergila presents amphistomaty, and the stomata localized at level or elevated above the epidermal cells around them. Both stomata characteristics have been reported in Baccharis by different authors (Metcalfe \& Chalk, 1950; Budel et al., 2003, 2004; Budel \& Duarte 2007, 2008, 2010; Petenatti et al., 2007; Jasinski et al., 2014; Bobek et al., 2015, 2016; Ornellas et al., 2019). Metcalfe \& Chalk (1950) demonstrated that a significant number of plant species have amphistomatic leaves. Mott et al. (1982) suggested that the presence of stomata on both sides of the leaf has an adaptive significance, being a derived character and ecologically correlated with the increased leaf conductance of carbon dioxide in plants living in open areas and full sun environments or with high light intensity, with seasonal variations of water availability in the soil. Mott \& Michaelson (1991) established that high light intensity produce amphistomatic leaves in Ambrosia cordifolia (A. Gray) W. W. Payne (Asteraceae), and increase leaf thickness, photosynthetic capacity, and maximum stomatal conductance, because the presence of stomata on adaxial and abaxial sides would be reducing diffusional limitations to photosynthesis. Amphistomatic leaves are common of arid environment with high solar radiation and also it would be a manner to increase photosintetic process, because increase gas exchange proving more efficient when compared to hypostomatic leaves (Roth, 1984; Parkhurst, 1978; Arambarri et al., 2011; Carbone, 2015). Liesenfeld et al. (2019), analyzed morphology and anatomy traits of leaves in 34 species of Asteraceae inhabiting in extreme environmental conditions, and they also reported among the characteristics adaptive to xeric environments, the amphistomatic leaves.

Mesophyll. The isobilateral mesophyll found in B. notosergila has been reported for many Baccharis species (e. g., Oliveira \& Bastos, 1998; Budel \& Duarte, 2007, 2008, 2010; Petenatti et al., 2007; Jasinski et al., 2014; Barreto et al., 2015; Bobek et al., 2015, 2016; Tosoratto et al., 2016; Budel et al., 2018). Metcalfe \& Chalk (1950) noted the relationships among presence of adaxial stomata in plants with isobilateral organization of palisade mesophyll. The correlation among amphistomatic leaves and isobilateral mesophyll was also found by Arambarri et al. (2011). Nughes et al. (2013) studied the behavior of Celtis ehrenbergiana (Klotzsch) Liebm., plants growing under temperate and wet weather with available water, and the leaves exposed to a high light intensity were amphistomatic with isobilateral or homogeneous (palisade parenchyma) mesophyll, whereas the leaves expanded under low light intensity were hypostomatic with dorsiventral mesophyll. Ornellas et al. (2019) had similar results studying six species of Baccharis inhabiting in the high-altitude grasslands, they found the occurrence of stomata and the mesophyll organization seem to be correlated, the amphistomatic leaves tend to be isobilateral.

Trichomes. Glandular trichomes were found in aerial vegetative organs of $B$. notosergila: (i) Biseriate capitate glandular, (ii) Bulbiferous flagelliform glandular type II, and rarely type I, that accords well with description provided by Tosoratto et al. (2016) and Budel et al. (2018), and (iii) Uniseriate capitate glandular which was previously reported by Petenatti et al. (2007) for B. sagittalis (Less.) DC. and B. triangularis Hauman. The biseriate capitate and flagelliform trichomes have been found in nearly all Baccharis 


\section{A. V. Carbone et al. - Baccharis notosergila: aerial vegetative organs and environment}

species. They have been cited for the genus by Ariza Espinar (1973) who namely "pilose nests", and have been reported for $B$. notosergila by Freire et al. (2007) and Heiden et al. (2009), and in other species of Baccharis (e. g., Cortadi et al., 1999; Budel \& Duarte, 2007, 2008; Budel et al., 2003, 2004, 2012, 2015, 2018; Freire et al., 2005; Petenatti et al., 2007; Souza et al., 2011; Jasinski et al., 2014; Pereira et al., 2014; Barreto et al., 2015; Bobek et al., 2015, 2016). For many years, the flagelliform trichomes were described as non-glandular trichome multicellular with a whip-like apical cell with different characteristics (e. g., Ramayya, 1962; Ariza Espinar, 1973; Freire et al., 2007). However, Budel et al. (2012, 2015) reported positive test for lipophilic compounds in basal cells. Tosoratto et al. (2016) studying $B$. salicifolia described the flagelliform trichomes as glandular bulbiferous flagelliform. Budel et al. (2018) described and illustrated the secreted substances in the body and apical cell of the flagelliform trichomes, and they suggested that these flagelliform glandular trichomes have two functional properties for protection and secretion. They also reported two forms of flagelliform trichomes, type I and type II, with straight and curved body, respectively. Ornellas et al. (2019) also cited the glandular flagelliform trichomes in other species of Baccharis. The lipophilic substances secreted by glandular trichomes and deposited on the leaves form an oily layer that increase the impermeability and reduce transpiration (Haberlandt, 1928). In this way, trichomes help prevent leaf overheating and water loss by transpiration process (Johnson, 1975; Ehleringer \& Mooney, 1978; Fahn \& Cutler, 1992; García et al., 2008). Glandular trichomes are an important source of essential oils having different uses, although many of these substances have evolved to provide the plant with protection against herbivores and pathogens (Glas et al., 2012). Trichomes may also complement the chemical defense of a plant by possessing internal secretion of phenolics, alkaloids and other repellent substances (Levin, 1973; Delbon et al., 2012). Minteguiaga (2019) studying species of Baccharis found the oil droplets secreted by trichomes are essential oils that have bioactive properties (e. g., garrapaticide, insecticide, fungicide) for example in B. dracunculifolia DC., and B. tridentata Vahl.
Fibers and endodermis. Baccharis notosergila showed scarce fibers in the leaves, frequently reduced to xylem side in the vascular bundles. However, they were abundant in the secondary xylem of the stem. Also, the stem showed the endodermis with Casparian strips surrounding the vascular system. These stem characteristics were also found by Tosorato et al. (2016) in B. salicifolia Nutt. According to Fahn \& Cutler (1992) the presence of fibers and endodermis are xeromorphic traits with the function to protect tissues of the dehydration.

Oil bodies. These lipid bodies were identified in the leaf mesophyll of $B$. notosergila. They were mentioned for the genus by Budel et al. (2018) and Ornellas et al. (2019). According to Pihakaski et al. (1987), there is a seasonal fluctuation in storage lipids, it would be increasing in the growing period. It may be seen large lipid bodies in summer but several small spherules in winter. Lersten et al. (2006) referred the presence of oil bodies in leaf mesophyll cells of many Angiosperms, and indicated the Asteraceae as one of the families in which the highest number of species have lipid bodies. Gidda et al. (2016) reported that environmental conditions such as dark and extreme temperatures (heat and cold) induce oil body formation, so they also suggested leaf oil bodies function in stress response. The function of the leaf oil bodies still are under study, however, Shimada et al. (2014) showed that the leaf oil bodies function as subcellular factories for the production of a novel stable phytoalexin (antimicrobial compounds that are synthesized after stresses) in response to fungal infection and senescence. Shimada et al. (2018) reported that oil bodies are lipid storage compartments that occur primarily in seeds and senescing leaves, and concluded the oil bodies have multiple functions, in seeds, seedlings and in leaf. In the leaves, the energy accumulated in oil bodies has a defensive role against fungal infection because they produce antifungal compounds.

Secretory ducts and chemical substances secreted. The secretory ducts were found in leaves and stems of $B$. notosergila. They were previously found in the roots of $B$. notosergila by Carbone et al. (2019). In cross sections of leaves, frequently, there is one duct associated to each vascular 
bundle, but may be seen two or three at middle vein level and coincidently in the main vascular bundle of the petiole. The presence of more than one duct was previously documented by Budel et al. (2018) and reported by Ornellas et al. (2019) for B. platypoda DC. and B. stylosa Gardner. It has been established for Asteraceae the principal substances secreted are volatile oils (Budel et al., 2012; Jasinski et al., 2014). The secretory ducts in $B$. notosergila have given positive reaction for resins, polyphenols, and oils. It was also found in B. notosergila subterranean system by Carbone et al. (2019), and it is in agreement with Ariza Espinar (1973) who reported that the secretory ducts may be releasing other chemical components such as tannins and resins besides essential oils. The resins could protect the plant against insects as occur in coniferous (Johnson \& Croteau, 1987). Cobos et al. (2001) analyzed the composition of the essential oils in aerial organs of $B$. notosergila, and they found 32 constituents and $\alpha$-pinene, limonene, $\beta$-caryophyllene, and the spathulenol as the major components. Budel et al. (2018) and Minteguiaga (2019) indicated that Baccharis species produce volatile oils that mainly contain sesquiterpenes and monoterpenes. Internal secretion of terpens and other secondary metabolites (e. g., flavonoids, tannins, resins) would help protect the plant from herbivores and pathogens, and contributing to the water balance (Fahn \& Cutler, 1992; Delbon et al., 2012; Tosoratto et al., 2016). Essential oils components are produced in most plant organs and they are stored in secretory structures (glandular trichomes and internal ducts). Chemically essential oils are complex mixture which have biology effects (e.g., antimicrobial, analgesic, antioxidants, sedative, antiinflamatory, and mutagenic, phototoxic and citotoxic) (Budel \& Duarte, 2008; Minteguiaga, 2019). In Baccharis has been isolated and identified more than 500 compounds, the most frequent would be essential oils, terpenoids, and flavonoids (Minteguiaga, 2019).

Phenolic compounds. Tannins were identified in the epidermal tissue and mesophyll of leaves. In stem in the secondary protection tissues, and were also found in the secondary xylem which is in agreement with the localization reported by Carbone et al. (2019) in the xylopodium of B. notosergila. Similar results were reported in different species of the genus by Tosoratto et al. (2016), Budel et al. (2018), and Ornellas et al. (2019). Tannins are phenolic compounds of high molecular weight, and may be found in all organs of plants. The presence of tannins is an adaptation to the high incidence of sunshine to protect against oxidative stress affecting the photosynthesis (Hassanpour et al., 2011). The sites of tannin production were the large cells located in the leaf mesophyll, plants can accumulate phenolic compounds in the leaf epidermis and mesophyll tissues, where its protective feature became evident against the UV radiation damage (Hassanpour et al., 2011). Del Valle et al. (2020) established the UV radiation increased the concentration of phenolic compounds (tannins, flavonoids, anthocianins) suggesting a photoprotective role against UV light. On the other hand, secondary metabolites of phenolic nature play an important role in the defensive response, e. g., phytoalexins who behave as inducer or elicitors of plant defense mechanisms (Ebel, 1986; Boller, 1989; Stone, 1989). Currently, research suggests that phytoalexins are a biochemical mechanism possessed by plants for disease tolerance and pathogen attacks (Ryan, 1987).

By other way, during the fieldwork was found a reduction of Stipa population around the $B$. notosergila plants (M. Oyhamburu \& F. Fernández, personal communication, October 20, 2020). This is a new line to research, on the basis that numerous compounds of phenolic nature act as allelopathic agents inhibiting the germination and growth of other species around plants (Rice, 1984). Although there are few reports the Baccharis species allelopathic effects, Dias et al. (2017) probed an allelopathic potential of phenolic compounds using an ethanolic and aqueous extracts from aerial parts of Baccharis spp.

Starch grains. These were identified in the guard cells of stomata, in the chlorenchyma of leaves and stems, in the last also in the secondary phloem. However, this polysaccharide was not detected in subterranean organs (Carbone et al., 2019). We did not find starch grains in the parenchyma sheath surrounding the vascular bundles as was cited by Budel et al. (2018). Thus, we believe the starch grains presence and quantity is variable in relation with the period of the year in which the leaves and aerial stems are collected. 


\section{A. V. Carbone et al. - Baccharis notosergila: aerial vegetative organs and environment}

Calcium oxalate crystals ( $\mathrm{CaOx})$. Crystals were found in the mesophyll of leaves, in pith and medullary rays of stems, and in the head cells of the glandular capitate trichomes of $B$. notosergila. Carbone et al. (2019) recorded abundant styloids in medullary rays of the xylopodium and roots of the same species. These crystal types and others were revealed for the genus by previous authors, coincidentally in the mesophyll of leaves, and the perimedullary region of stems (Cortadi et al., 1999; Budel et al., 2003, 2004; Petenatti et al., 2007; Budel \& Duarte, 2010; Jasinski et al., 2014; Bobek et al., 2015, 2016; Budel et al., 2015, 2018). Many reasons have been written about the formation and functions of $\mathrm{CaOx}$ in plants, such as the functions attributed to the calcification process include the elimination of oxalate in those plants unable to metabolize it, protection against herbivores (Molano-Flores, 2001), being a source of calcium reserve (Volk et al., 2002), the detoxification of heavy methals (Nakata, 2003). Franceschi \& Nakata (2005) communicated the crystals are formed in specific shapes and sizes, and genetic regulation of $\mathrm{CaOx}$ formation is indicated by constancy of crystal morphology within species. The same authors, also mentioned as the major functions of $\mathrm{CaOx}$ crystals in plants include high-capacity calcium regulation, and protection against herbivores. Apóstolo (2005) reported high $\mathrm{pH}$ values in the soil promote formation of crystals in plants, and Garcia et al. (2008) indicated the presence of crystals in leaf mesophyll would be associated to saline/alkaline soils. In $B$. notosergila, we have seen small crystals in mesophyll cells of leaves collected in sweet lowland and half hill, but not observed in the leaves from alkaline-saline soils. On the basis of these data we infer that there might be several factors promoting the formation of calcium oxalate crystals.

\section{Conclusions}

This study allows us to achieve an interpretation about the adaptive characteristics of $B$. notosergila which shows higher stress tolerance and competitive ability. A number of meso-xeromorphic characters are found in $B$. notosergila, such as small, narrow and deciduous leaves; the hydathodes presence; epidermal cells with straight cell walls; massive and striate cuticle; glandular trichomes secreting oily substances; stomata at level or above the other epidermal cells; presence of tannins in leaves and stem tissues; oily bodies in mesophyll cells; a moderate quantity of fibers; presence of endodermis with Casparian strips; amphistomatic leaves and isobilateral mesophyll. Among them the epidermal tissue, cuticle and epicuticular waxes covered by an oily layer, and presence of tannins would be a physical and chemical barrier for dehydration as well as the penetration of the herbicides applied for its control. The mentioned characteristics adding the abundant lipophilic substances, the presence of fibers and endodermis in stems would be producing tolerance to lowland areas and the alternate of drought and flooding periods which are common in the studied region. The stomata localized at level or slightly elevated and scarce sclerenchyma are mesomorphic traits corresponding to a luminous temperate weather in which $B$. notosergila inhabit, and the combination amphistomatic leaves with isobilateral mesophyll promote more efficient photosynthesis process. As a matter of fact, leaves are present during springsummer, with favorable environmental conditions contributing plants produce as many resources as possible to storage in its deep root system, ensuring the survival during the unfavorable period, and providing the capacity to sprout and resprout from the bud-bank (xylopodium), restoring the plant aerial parts in the following spring.

\section{AUTHOR CONTRIBUTIONS}

AVC provided the global research ideas and goals, and with FEF provided the resources and fieldwork data and interpretation. MPH, SMMA and AMA carried out the laboratory research. AMA, AVC and MPH prepared the first manuscript. All authors have read and contributed to write the final manuscript.

\section{AcKNOWLedgements}

We thank the technicians Mario Sánchez and Mariela Theiller of CINDECA-CONICET-UNLP for the electron microscope service. 


\section{Bibliography}

APÓSTOLO, N. M. 2005. Caracteres anatómicos de la vegetación costera del Río Salado (Noroeste de la provincia de Buenos Aires, Argentina). Bol. Soc. Argent. Bot. 40: 215-227.

APPEZZATO-DA-GLÓRIA, G. \& G. CURY. 2011. Morpho-anatomical features of underground systems in six Asteraceae species from the Brazilian Cerrado.An. Acad. Bras. Ciênc. 83: 981-991.

ARAMBARRI, A. M., M. C. NOVOA, N. D. BAYÓN, M. P. HERNÁNDEZ, M. N. COLARES \& C. MONTI. 2011. Ecoanatomía foliar de árboles y arbustos de los Distritos Chaqueños Occidental y Serrano (Argentina). Bol. Soc. Argent. Bot. 46: 251-270.

ARIZA ESPINAR, L. 1973. Las especies de Baccharis (Compositae) de Argentina Central. Bol. Acad. Nac. Ci. 50: 1-305.

ASH, A., B. ELLIS, L. J. HICKEY, K. JOHNSON, P. WILF \& S. WING. 1999. Manual of leaf architecture- morphological description and categorization of dicotyledonous and nerveined monocotyledonous angiosperms by Leaf architecture working group. Smithsonian Institution, Washington, D. C.

BARTHLOTT, W., C. NEINHUIS, D. CUTLER, F. DITSCH, I MEUSEL, I. THEISEN \& H. WILHELM. 1998. Classification and terminology of plant epicuticular waxes. Bot. J. Linn. Soc. 126: 237-260. https://doi.org/10.1111/j.1095-8339.1998.tb02529.x

BARRETO I. F., J. PADILHA DE PAULA, P. V. FARAGO, M. R. DUARTE \& J. M. BUDEL. 2015. Pharmacobotanical study of the leaves and stems of Baccharis ochracea Spreng. for quality control. Lat. Am. J. Pharm. 34: 1497-1502.

BOBEK, V. B., V. P. DE ALMEIDA, C. B. PEREIRA, G. HEIDEN, M. R. DUARTE, J. M. BUDEL \& T. NAKASHIMA. 2015. Comparative pharmabotanical analysis of Baccharis caprariifolia DC. and B. erioclada DC. From Campos Gerais, Paraná, Southern Brazil. Lat. Amer. J. Pharm. 34: 1396-1402.

BOBEK, V.B., G. HEIDEN, C. FREITAS DE OLIVEIRA, V. PAES DE ALMEIDA, J. PADILHA DE PAULA, P. V. FARAGO, T. NAKASHIMA \& J. M. BUDEL. 2016. Comparative analytical micrographs of "vassouras" (Baccharis, Asteraceae). Rev. Bras. Farmacogn. 26: 665-672.

https://dx.doi.org/10.1016/j.bjp.2016.05.001
BOLLER, T. 1989. Primary signals and second messengers in the reaction of plants to pathogens. In BOSS, W. F. \& D. J. MORRÉ (eds.), Second Messengers in Plant Growth and Development, pp. 227-255. Alan R. Liss, New York.

BUDEL, J. M., M. R. DUARTE, C. A. M. SANTOS \& L. M. CUNHA. 2003. Macro and microscopical identification of four species of Baccharis from Trimera group. Rev. Bras. Farmacogn. 13: 42-43. http://dx.doi.org/10.1590/S0102-695X2003000400014

BUDEL, J. M., M. R. DUARTE, C. A. M. SANTOS. 2004. Stem morpho-anatomy of Baccharis cylindrica (Less.) DC. (Asteraceae). Braz. J. Pharm. Sci. 40: 93-99. http://dx.doi.org/10.1590/S1516-93322004000100014

BUDEL, J. M. \& M. R. DUARTE. 2007. Caracteres morfoanatômicos de partes vegetativas aéreas de Baccharis coridifolia DC. (Asteraceae-Astereae). Lat. Amer. J. Pharm. 26: 723-731.

BUDEL, J. M. \& M. R. DUARTE. 2008. Estudo farmacobotânico de folha e caule de Baccharis uncinella DC., Asteraceae. Lat. Amer. J. Pharm. 27: 740-760.

BUDEL, J. M. \& M. R. DUARTE. 2010. Macro and microscopic characters of the aerial vegetative organs of carqueja: Baccharis usterii Heering. Braz. Arch. Biol. Technol. 53: 123-131.

https://oi.org/10.1590/S1516-89132010000100016

BUDEL, J. M., M. R. DUARTE, P. M. DÖLlBOSCARDIN, P. V. FARAGO, N. I. MATZENBACHER, A. SARTORATTO \& B. H. L. N. SALES MAIA. 2012. Composition of essential oils and secretory structures of Baccharis anomala, B. megapotamica and B. ochracea. J. Essent. Oil Res. 24: 19-24.

https://doi.org/10.1080/10412905.2012.645634

BUDEL, J. M., J. PADILHA DE PAULA, V. L. PEREIRA DOS SANTOS, C. R. CAVICHIOLO FRANCO, P. V. FARAGO \& M. R. DUARTE. 2015. Pharmacobotanical study of Baccharis pentaptera. Rev. Bras. Farmacogn. 25: 314-319. http://dx.doi.org/10.1016/j.bjp.2015.07.007

BUDEL, J. M., V. RAMAN, L. M. MONTEIRO, V. P. ALMEIDA, V. B. BOBEK, G. HEIDEN, I. J. M. TAKEDA \& I. A. KHAN. 2018. Foliar anatomy and microscopy of six Brazilian species of Baccharis (Asteraceae). Microsc. Res. Tech. 1-11. https://doi.org/10.1002/jemt.23045

CARBONE, A.V. 2015. Caracterización morfo-anatómica de dos poblaciones de Gomphrena perennis L. y su 


\section{A. V. Carbone et al. - Baccharis notosergila: aerial vegetative organs and environment}

posible relación con la sensibilidad al herbicida glifosato. Tesis de Maestría Protección Vegetal. Facultad de Ciencias Agrarias y Forestales, Universidad Nacional de La Plata. Repositorio Institucional de la UNLP. Disponible en: http:// sedici.unlp.edu.ar/bitstream/handle/10915/48707/ Documento_completo.pdf - P D F A. pdf?sequence $=3 \&$ is Allowed $=y$

CARBONE, A. V., F. E. FERNÁNDEZ, M. P. HERNÁNDEZ \& A. M. ARAMBARRI. 2019. Morphoanatomy, histochemistry and crystals of the underground system of Baccharis notosergila (Asteraceae). Bol. Soc. Argent. Bot. 54: 519-532. http://dx.doi.org/10.31055/1851.2372.v54.n4.24930

COBOS, M. I., J. L. RODRÍGUEZ, M. M. OLIVA, M. DEMO, S. M. FAILLACI \& J. A. ZYGADLO. 2001. Composition and antimicrobial activity of the essential oil of Baccharis notosergila. Planta Med 67: 84-86. https://doi.org/10.1055/s-2001-10633

CORTADI, A., O. DI SAPIO, J. Mc CARGO, A. SCANDIZZI, S. GATTUSO \& M. GATTUSO. 1999. Anatomical studies of Baccharis articulata, Baccharis crispa and Baccharis trimera, "carquejas" used in folk medicine. Pharm. Biol. 37: 357-365. https://doi.org/10.1076/phbi.37.5.357.6054

COSA, M. T. \& N. DOTTORI. 2010. Adaptaciones anatómicas de plantas medicinales a la diversidad de ambientes, $73 \mathrm{pp}$. Curso de actualización Profesional, X Simposio Argentino y XIII Simposio Latinoamericano de Farmacobotánica, Córdoba.

COSA, M. T., N. DOTTORI, L. STIEFKENS, M. HADID, M. MATESEVACH, N. DELBÓN, P. WIEMER, S. MACHADO, V. CABRERA, C. COSTA, A. PÉREZ \& A. TRENCHI. 2014. Aplicación de técnicas de histología vegetal a la resolución de diversos problemas. Laboratorio de Morfología Vegetal, Universidad Nacional de Córdoba, Argentina.

DALL'ARMELLINA, A. A. \& R. L. ZIMDAHL. 1989. Effect of watering frequency, drought, and glyphosate on growth of field bindweed (Convolvulus arvensis). Weed Sci. 37: 314- 318. https://www.jstor.org/ stable $/ 4044715$

D'AMBROGIO, A. 1986. Manual de técnicas en histología vegetal. Hemisferio Sur, Buenos Aires, Argentina.

DELBÓN, N., M. T. COSA \& G. BERNARDELLO. 2012. Exomorfología y anatomía de órganos vegetativos aéreos en especies de Flourensia DC. (Asteraceae) con importancia fitoquímica. Acta Bot. Brasil. 26: 2-10. https://doi.org/10.1590/S0102-33062012000100002
DEL VALLE, J. C., M. L. BUIDE, J. B. WHITTALL, F. VALLADARES \& E. NARBONA. 2020. UV radiation increases phenolic compound protection but decreases reproduction in Silene littorea. PLoS One 15: e0231611. https://doi.org/10.13371/journal. pone.0231611.eCollection2020

DIAS, M. P., R. M. NOZARI \& E. R. SANTARÉM. 2017. Herbicidal activity of natural compounds from Baccharis spp. On the germination and seedlings growth of Lactuca sativa and Bidens pilosa. Allelopathy J 42: 21-36. $\mathrm{h} \mathrm{t} \mathrm{t} \mathrm{p} \mathrm{s} \mathrm{:} \mathrm{//} \mathrm{d} \mathrm{o} \mathrm{i} \mathrm{.}$ org/10.26651/2017-42-1-1103

EBEL, J. 1986. Phytoalexin synthesis: The biochemical analysis of the induction process. Ann. Rev. Phytopathol. 24: 235-264. https://doi.org/10.1146/ annurev.py.24.090186.001315

EHLERINGER, J. R. \& H. A. MOONEY. 1978. Leaf hairs: effects on physiological activity and adaptive value to a desert shrub. Oecologia 37: 183-200. https://doi.org/10.1007/BF00344990

FAHN, A. \& D. CUTLER. 1992. Xerophytes, pp. 1-143 Handbuchder Pflanzenantomie 13, 3. Gebruder Borntraeger, Berlín.

FRANCESCHI, V. R. \& P. A. NAKATA. 2005. Calcium oxalate in plants: formation and function. Annu. Rev. Plant Biol. 56: 41-71.

https://doi.org/10.1146/annurev. arplant.56.032604.144106

FRANKLIN, G. L. 1945. Preparation of thin sections of synthetic resins and wood-resin composites, and a new macerating method for wood. Nature 155: 51. https://doi.org/10.1038/155051a0

FREIRE, S. E., A.M. ARAMBARRI, N. D. BAYÓN, G. SANCHO, E. URTUBEY, C. MONTI, M. C. NOVOA \& M. N. COLARES. 2005. Epidermal characteristics of toxic plants for cattle from the Salado river basin (Buenos Aires, Argentina). Bol. Soc. Argent. Bot. 40: 241-281.

FREIRE, S. E., E. URTUBEY \& D. A. GIULIANO. 2007. Epidermal characters of Baccharis (Asteraceae) species used in traditional medicine. Caldasia 29: 23-38. https://dx.doi.org/10.15446/caldasia

GARCIA, M., D. JÁUREGUI \& E. MEDINA. 2008. Adaptaciones anatómicas foliares en especies de angiospermas que crecen en la zona costera del Estado Falcón (Venezuela). Acta Bot.Venez. 31: 291-306.

GIDDA, S. K., S. PARK, M. PYC, O. YURCHENKO, Y. CAI, P. WU, D. W. ANDREWS, K. D. CHAPMAN, J. M. DYER \& R. T. MULLEN. 2016. Lipid droplet- 
associated proteins (LDAPs) are required for the dynamic regulation of neutral lipid compartmentation in plant cells. Plant Physiol. 170: 2052-71. https://doi.org/10.1104/pp.15.01977.Epub 2016 Feb 19 GIULIANO, D. A. \& A. PLOS. 2014. Baccharis. En: ZULOAGA, F. O., M. J. BELGRANO \& A. M. ANTON (eds.). Flora Argentina: flora vascular de la República Argentina, Dicotyledoneae, Asteraceae, 7: 43-123. Estudio Sigma S. R. L., Buenos Aires.

GLAS, J. J., B. C. J. SCHIMMEL, J. M. ALBA, R. ESCOBAR-BRAVO, R. C. SCHUURINK \& M. R. KANT. 2012. Plant glandular trichomes as targets for breeding of engineering of resistance to herbivores. Int. J. Mol. Sci. 13: 17077-17103. https://doi.org/10.3390/ijms131217077

GONZÁLEZ, A. M. 2018. Image J: una herramienta indispensable para medir el mundo biológico. Sociedad Argentina de Botánica. Folium (Relatos botánicos) 1: 6-17.

GURR, E. 1971. Synthetic dyes in biology, medicine and chemistry. Academic Press, London.

HABERLANDT, G. 1928. Physiological plant anatomy. Macmillan, London.

HASSANPOUR S., N. MAHERI-SIS, B. ESHRATKHAH \& F. B. MEHMANDAR. 2011. Plants and secondary metabolites (Tannins): a review. Int. J. Forest, Soil and Erosion 1: 47-53. Available at: www.ijfse.com. [Accessed: 15 June 2020].

HAYASHI, A. H. \& B. APPEZZATO-DA-GLÓRIA. 2007. Anatomy of the underground system in Vernonia grandiflora Less. and $V$. brevifolia Less. (Asteraceae). Braz. Arch. Biol. Technol. 50: 979-988. http://dx.doi.org/10.1590/S151689132007000700009

HEIDEN, G., J. R.VIEIRA IGANCI \& L. MACIAS. 2009. Baccharis sect. Caulopterae (Asteraceae, Astereae) no Rio Grande do Sul, Brasil. Rodriguesia 60: 943983. https://doi.org/10.1590/2175-7860200960411

HEIDEN, G., A. ANTONELLI \& J. R. PIRANI. 2019. A novel phylogenetic infrageneric classification of Baccharis (Asteraceae: Astereae), a highly diversified American genus. Taxon 68: 1048-1081. https://doi.org/10.1002/tax.12128

INSTITUTO DE BOTÁNICA DARWINION. Available at: http://www2.darwin.edu.ar/floraargentina// fa.htm. (Accessed: 15 June 2020).

JASINSKI, V. C. G., R. Z. da SILVA, R. PONTAROLO, J. M. BUDEL \& F. R. CAMPOS. 2014. Morphoanatomical characteristics of Baccharis glaziovii in support of its pharmacobotany. Rev.
Bras. Farmacogn. 24: 609-616. https://doi.org/10.1016/j.bjp.2014.11.003

JOHANSEN, D. A. 1940. Plant microtechnique. McGraw-Hill Book Company, New York.

JOHNSON, H. B. 1975. Plant pubescence: an ecological perspective. Bot. Rev. 41: 233- 258. https://doi.org/10-1007/BF02860838

JOHNSON, M. A. \& R. CROTEAU. 1987. Biochemistry of conifer resistance to bark beetles and their fungal symbionts. In: Fuller, G. \& W. D. Nes (eds.). Ecology and Metabolism of Plant Lipids, pp. 76-92. American Chemical Society, Washington, D.C.

LERSTEN, N. R. \& J. D. CURTIS. 1985. Distribution and anatomy of hydathodes in Asteraceae. Int. $J$. Plant Sci. 146: 106-114.

LERSTEN, N. R., A. R. CZLAPINSKI, J. D. CURTIS, R. FRECKMANN \& H. T. HORNER. 2006. Oil bodies in leaf mesophyll cells of angiosperms: overview and a selected survey. Am. J. Bot. 93: 1731-1739. https://doi.org/10.3732/ajb.93.12.1731

LEVIN, D. 1973. The role of trichomes in plant defense. QRev Biol 48: 3-15.

LIESENFELD, V., P. GENTZ, E. M. DE FREITAS \& S. MARTINS. 2019. Leaf morphology and anatomy of Asteraceae of the Pampas biome (sand-fields). FLORA 258, Article 151418. https://doi.org/10.1016/j.flora.2019.151418

LUQUE, R., H. C. SOUSA \& J. E. KRAUS. 1996. Métodos de coloração de Roeser (1972)-modificadoe Kropp (1972) visando a substituição do azul de astra por azul de alcião $8 \mathrm{GS}$ ou $8 \mathrm{GX} /$ Staining methods of modified Roeser (1972) and Kropp (1972), aiming at substituting the astra blue by alcian blue $8 \mathrm{GS}$ or 8GX. Acta Bot. Bras. 10: 199 - 212. http://dx.doi.org/10.1590/S0102-33061996000200001

MERIDA, T., J. SCHÖNHERR \& H. W. SCHMIDT. 1981. Fine structure of plant cuticles in relation to water permeability: the fine structure of the cuticle of Clivia miniata reg. leaves. Planta 152: 259-267. https://doi.10.1007/BF00385154

METCALFE, C. R. \& L. CHALK. 1950. Anatomy of the Dicotyledons. Clarendon Press, Oxford.

METCALFE, C. R. \& L. CHALK. 1988. Anatomy of the Dicotyledons. Systematic anatomy of the leaf and stem. Clarendon Press, Oxford.

MINTEGUIAGA, M. 2019. Fitoquímica de Baccharis spp. L. (Asteraceae): metabolitos secundarios, semisintesis y bioactividad, pp. 577. Tesis presentada para aspirar al título de Doctor en Química. Cátedra de Farmacognosia y Productos Naturales, Laboratorio 


\section{A. V. Carbone et al. - Baccharis notosergila: aerial vegetative organs and environment}

de Biotecnología de Aromas, Facultad de Química, Universidad de la República (UdelaR), Montevideo, Uruguay.

MOLANO-FLORES, B. 2001. Herbivory and calcium concentrations affect calcium oxalate crystal formation in leaves of Sida (Malvaceae). Ann. Bot. 88: 387-391.

https://doi.org/10.1006/anbo.2001.1492

MOTT, K. A., C. A. GIBSON \& J. W. O’LEARY. 1982. The adaptive significance of amphistomatic leaves. Plant Cell Environ. 5: 455-460. https://doi.org/10.1111/1365-3040.ep11611750

MOTT, K. A. \& O. MICHAELSON. 1991. Amphistomaty as an adaptation to high light intensity in Ambrosia cordifolia (Compositae). Amer. J. Bot. 78: 76-79. https://doi.org/10.1002/j.1537-2197.1991.tb12573.x

MÜLLER, J. 2013. World checklist of Baccharis L. (Compositae-Astereae), version 2013-09-03, pp. 170. Herbarium Haussknecht, Friedrich-SchillerUniversität, Jena.

NAKATA, P. A. 2003. Advances in our understanding of calcium oxalate crystal formation and function in plants. Plant Science 164: 901-909. https://doi.org/10.1016/S0168-9452(03)00120-1

NUGHES, L., M. COLARES, M. HERNÁNDEZ \& A. ARAMBARRI. 2013. Morfo-anatomía de las hojas de Celtis ehrenbergiana (Celtidaceae) desarrolladas bajo condiciones naturales de sol y sombra. Bonplandia 22: 47-58. http://dx.doi.org/10.30972/bon.2221245

O`BRIEN, T. P., N. FEDER \& M. E. MC CULLY. 1964. Polychromatic stained of plant cell walls by toluidine blue O. Protoplasma 59: 368-373. https:// doi.org/10.1007/BF01248568

OLIVEIRA, V. C. \& E. M. BASTOS. 1998. Aspectos morfo-anatômicos da folha de Baccharis dracunculifolia DC. (Asteraceae) visando a identificação da origem botánica da própolis. Acta Bot. Bras. 12: 431-439.

https://doi.org/10.1590/S0102-33061998000400012

OLIVEIRA, A.M.A., V.L.P. SANTOS, C.R.C. FRANCO, P.V. FARAGO, M.R. DUARTE \& J.M BUDEL. 2011. Comparative morpho-anatomy study of Baccharis curitybensis Heering ex Malme and Baccharis spicata (Lam.) Baill. Lat. Am. J. Pharm. 30: 1560-1566.

ORNELLAS, T., G. HEIDEN, B. NUNES DE LUNA \& C. FRANCA BARROS. 2019. Comparative leaf anatomy of Baccharis (Asteraceae) from high-altitude grassland in Brazil: taxonomic and ecological implications. Botany 97: 615-626. NRC

Research Press.

https://dx.doi.org/10.1139/cjb-2019-0035

PARKHURST, D. F. 1978. The adaptative significance of stomatal occurrence on one or both surfaces of leaves. J. Ecol. 66: 367-383. https://doi.org/10.2307/2259142

PEREIRA, C.B., P.V. FARAGO, J.M. BUDEL, J.P. DE PAULA, D.G. FOLQUITTO \& O. G. MIGUEL \& M. D. MIGUEL. 2014. A new contribution to the pharmacognostic study of carquejas: Baccharis milleflora DC., Asteraceae. Lat. Am. J. Pharm. 33: 841-847.

PÉREZ, A. \& V. H. TOMASI. 2002. Tinción con azul brillante de cresilo en secciones vegetales con parafina. Bol. Soc. Argent. Bot. 37: 211-215.

PETENATTI, E. M., M. E. PETENATTI, D. A. CIFUENTE, J. C. GIANELLO, O. S. GIORDANO, C. E. TONN \& L. A. DEL VITTO. 2007. Medicamentos herbarios en el Centro-Oeste Argentino. VI. Caracterización y control de calidad de dos especies de "carquejas": Baccharis sagittalis y B. triangularis (Asteraceae). Lat. Am. J. Pharm. 26: 201-208.

PIHAKASKI, K., S. PIHAKASKI, P. KARUNEN \& P. KALLIO. 1987. Seasonal changes in leaf lipids of Diapensia japponica, with special reference to storage lipid bodies. Nord. J. Bot. 7: 281-292. https:// doi.org/10.1111/j.1756-1051.1987.tb00945.x

RAMAYYA, N. 1962. Studies on the trichomes of some Compositae I. General structure. Bull. Bot. Surv. India 4: 177-188.

RICE, E.L. 1984. Allelopathy, Second edition. Academic Press, New York.

RODRIGUEZ, A \& E. JACOBO. 2012. Manejo de pastizales naturales para una ganadería sustentable en la Pampa Deprimida. Buenas prácticas para una ganadería sustentable de pastizal. Kit de extensión para las pampas y campos. Editorial FAUBA, Buenos Aires.

ROTH, I. 1984. Stratification of tropical forests as seen in leaf structure. In Encyclopedia of plant anatomy, Gebrüder Borntraeger, Berlin.

RUZIN, S. E. 1999. Plant microtechnique and microscopy. University Press, Oxford.

RYAN, C.A. 1987. Oligosaccharide signaling in plants. Annu Rev Cell Biol 3: 295-317. https://doi.org/10.1146/annurev.cb.03.110187.001455

SANTIER, S. \& A. CHAMEL. 1992. Penetration of glyphosate and diuron into and through isolated 
plant cuticles. Weed Res. 32: 337-347. https://doi.org/10.1111/j.1365-3180.1992.tb01894.x SHIMADA, T. L., Y. TAKANO, T. SHIMADA, M. FUJIWARA, Y. FUKAO, M. MORI, Y.OKAZAKI, K. SAITO, R. SASAKI, K. AOKI \& I. HARANISHIMURA. 2014. Leaf oil body functions as a subcellular factory for the production of a phytoalexin in Arabidopsis. Plant Physiol. 164: 105118. https://doi.org/10.1104/pp.113.230185

SHIMADA, T. L., M. HAYASHI \& I. HARANISHIMURA. 2018. Membrane dinamics and multiple functions of oil bodies in seeds and leaves. Plant Physiol. 176: 199-207. https://doi.org/10.1104/pp.17.01522

SIONE, S. M., R. A. SABATTINI, S. G. LEDESMA, A. F. DORSCH \& C. FORTINI. 2006. Caracterización florística y structural del estrato arbustivo de un monte en pastoreo (Las Garzas, Entre Ríos). Rev. Cient. Agropecu. 10: 59-67.

SMILJANIC, K. B. A. 1969. Anatomia foliar de espécies de Asteraceae de um afloramento rochoso no Parque Estadual da Serra do Brigadeiro (MG), Viçosa, pp.79. Tesis Magister Science. Universidade Federal de Viçosa, Brazil.

SOUZA, C. A. de, P. V. FARAGO, M. R. DUARTE \& J. M. BUDEL. 2011. Pharmacological study of Baccharis singularis (Vell.) G. M. Barroso, Asteraceae. Lat. Am. J. Pharm. 30: 311-317.

STENGLEIN, S., A. M. ARAMBARRI, M. C. MENÉNDEZ SEVILLANO \& P. A. BALATTI. 2005. Leaf epidermal characters related with plant's passive resistance to pathogens vary among accessions of wild beans Phaseolus vulgaris var. aborigineus (Leguminosae-Phaseoleae). Flora 200: 285-295. https://doi.org/10.1016/j.flora.2005.01.004

STONE, B. A. 1989. Cell walls in plant-microorganism associations. Aust. J. Plant Physiol. 16: 5-17. https://doi.org/10.1071/PP9890005
TAPIA-TORRES, N. A., C. de la PAZ-PÉREZ-OLVERA, A. ROMÁN GUERRERO, A. QUINTANARISAÍAS, E. GARCÍA-MÁRQUEZ \& F. CRUZSOSA. 2014. Histoquímica, contenido de fenoles totales y actividad antioxidante de hoja y de madera de Litsea glaucescens Kunth (Lauraceae). Madera y Bosques 20: 125-137.

TOSORATTO, N., M. T. COSA \& N. DELBÓN. 2016. Morfoanatomía e histoquímica de cuatro Asteraceae nativas del Bosque Chaqueño Serrano (Córdoba, Argentina). Bol. Soc. Argent. Bot. 51: 613-622.

URDAMPILlETA, J. I. 2019. Métodos de control poblacional de Baccharis notosergila Griseb.: maleza arbustiva de alta incidencia en la zona de la Pampa Deprimida. Tesis de grado, modalidad: intervención profesional, Facultad de Ciencias Agrarias y Forestales, Universidad Nacional de La Plata. Repositorio Institucional de la UNLP. Disponible en: http://sedici.unlp.edu.ar/handle/10915/74210

VOLK, G. M., V. J. LYNCH-HOLM, T. KOSTMAN, L. J. GOSS \& V. FRANCESCHI. 2002. The role of druse and raphide calcium oxalate crystals in tissue calcium regulation in Pistia stratioides leaves. Plant Biology 4: 34-45. https://doi.org/10.1055/s2002-20434

WESTWOOD, J. H., C. N. YERKES, F. P. DEGENNARO \& S. C. WELLER. 1997. Absorption and translocation of glyphosate in tolerant and susceptible biotypes of field bindweed (Convolvulus arvensis). Weed Sci. 45: 658-663. https://doi.org/10.1017/S0043174500093292

ZARLAVSKY, G. E. (ed.). 2014. Histología vegetal: Técnicas simples y complejas. Sociedad Argentina de Botánica, Buenos Aires.

ZULOAGA, F. O., M. J. BELGRANO \& C. A. ZANOTTI. 2019. Actualización del Catálogo de las plantas vasculares del Cono Sur. Darwiniana, nueva serie 7: 208-278. https://doi.org/10.14522/darwiniana.2019.72.861 